\title{
Economic and Monetary Integration in ECOWAS Countries: A Panel VAR Approach to Identify Macroeconomic Shocks
}

\author{
Asta Ndongo ${ }^{a}$ Ibrahima Thione Diop \\ Received: 09.09.2021; Revised: 14.11.2021; Accepted: 30.11.2021
}

This paper studies the impact of output, exchange rate, price, and economic policies (fiscal and monetary) shocks to Economic Community of West African States (ECOWAS) economies over the period 1977-2019. The results of the impulse response functions obtained from the panel VAR show that monetary policy shocks stimulate economic activity, whereas fiscal shocks lead to a contraction. Moreover, these economic policy shocks lead to an increase in the price level. Finally, they have opposite effects on the real exchange rate: a monetary policy shock leads to an appreciation of national currencies against the US dollar, while a fiscal innovation leads to a depreciation of these currencies. As for exchange rate and price shocks, they create inflation and consequently a decline in economic activity. Furthermore, the forecast error variance decomposition reveals that real exchange rate shocks contribute the most to future fluctuations in macroeconomic variables in ECOWAS countries. Moreover, a comparison of the impact on the two currency areas, West African Economic and Monetary Union (WAEMU) and West African Monetary Zone (WAMZ), shows the degree of asymmetry between the two areas. The analysis shows, on the one hand, that shocks are more persistent and significant in the WAMZ and, on the other hand, that except for real exchange rate shocks, the two zones respond asymmetrically to shocks emanating from the other variables.

JEL codes: C12, C53, F15, E32, F45

Keywords: Monetary integration; Macroeconomic shocks; Impulse response function; Forecast error variance decomposition

\section{Introduction}

Strengthening regional integration (economic and monetary) in West Africa is one of the major challenges for the future development of the subregion. Aware of this, the member countries of the Economic Community of West African States (ECOWAS) have decided to create a community currency.

\footnotetext{
a Corresponding author. Center for Applied Economic Research, Cheikh Anta DIOP University, Senegal (e-mail: asta.ndongo@ucad.edu.sn; astandongo1@gmail.com). (D) https://orcid.org/0000-0002-0177-3545

b Professor at the Faculty of Economics and Management of the Cheikh Anta Diop University, Senegal, Special Advisor to the Rector (email: ibrahimat.diop@ucad.edu.sn; thionediop@yahoo.fr). https://orcid.org/0000-0002-2868-3304
} 
Despite the efforts made, the project to create the single currency has been postponed several times, notably in 2005, 2009, 2013, 2015 and 2020, due to the failure of member countries to meet the convergence criteria. Indeed, the economic instability of the major powers, namely Nigeria and Ghana, which account for about $76 \%^{1}$ of the Community's GDP, the permanent exposure to external shocks because of their dependence on the export of basic commodities, insecurity, the low proportion of intra-Community trade, the diversity of currencies (eight different currencies), the inconvertibility of most of them and exchange rate distortions are some obstacles.

The synchronization of shocks is a crucial element for the viability of a monetary union. Without it, the costs of membership may be higher than the benefits, and the viability of the currency area will be jeopardized. Moreover, macroeconomic shocks can have a positive or negative impact on the economy of a given country and can affect the member countries of a monetary union asymmetrically. For example, an oil shock may not affect Nigeria in the same way as the other countries in the ECOWAS zone because it is the leading oil producer in Africa, while the others are importers.

Several studies have shown the weak or negative correlation of macroeconomic shocks affecting ECOWAS countries (Houssa, 2008; Mati et al., 2019; Debrun et al., 2005). However, these studies analyze the effects of shocks on each economy. Unlike previous studies, our study contributes by showing the impact of macroeconomic shocks in the ECOWAS zone.

According to Bernanke \& Gertler (1986), the shocks must be primitive exogenous forces that are uncorrelated with each other, and they must be economically significant. A fiscal policy shock is an unexpected change in government spending or taxes. There is a large literature on the effects of fiscal policy shocks (Blanchard \& Perotti, 2002; Beetsma et al., 2008; Mountford \& Uhlig, 2009; Boiciuc, 2015). As for monetary policy shocks, many authors argue that their sources are changes in central bank preferences (Nolan et al., 1996; Robert Nobay \& Peel, 2003) while for others, they do not stem solely from changes in the preference of policymakers (Debortoli \& Nunes, 2014). Monetary policy shocks are measured by variances in the money supply or interest rates. Regardless of the origin and/or nature of the shocks, determining their effects on economies that wish to form a monetary union is of critical importance.

Identification of macroeconomic shocks is not easy, as dynamic and general equilibrium effects must be taken into account. However, given the particular attention drawn to the economic and monetary union in the ECOWAS zone, we have very little evidence on the impact of real GDP, exchange rate, price, monetary and fiscal shocks on its economies as a whole. In this regard, the main objective of this paper is to study the effects of these shocks on the economies of the Community. Consequently, we will focus on identifying the nature of monetary and real shocks that could weaken the ECOWAS monetary union. Specifically, we will:

- identify real and monetary shocks that could weaken the future ECOWAS monetary zone;

- analyze the reactions of endogenous variables (real GDP, real exchange rate, price index, money supply and government spending) to monetary and real developments (impulse response function analysis);

${ }^{1}$ Source: Author's calculations 
- measure the impact of the variability of the variables on the future fluctuations of the other macroeconomic variables (decomposition of the variance of the forecast error);

- compare the responses of the two zones (WAEMU and WAMZ) to real and monetary innovations.

The rest of the study is organized as follows. The next section is an overview of the literature. Section 3 describes the data used in this study and section 4 presents the framework used to identify the sources of economic fluctuations. The results of the estimations will be analyzed and interpreted in Section 5 and finally, 6 completes the analysis.

\section{Literature Review}

Even though the founders of the New Classical School, Kydland \& Prescott (1982), assume that productivity shocks are exogenous and not influenced by other economic factors, others maintain that these shocks are endogenous (Evans, 1992). According to the latter, the influence of money supply, interest rates and public spending on the sources of future fluctuations in economic activity is significant.

Since the work of Christiano et al. (1999), the literature has focused on the effects of monetary policy shocks on macroeconomic variables. According to Friedman \& Schwartz (1963), the monetary contraction and errors of the Federal Reserve caused the Great Depression. According to Rogers (1999), the sources of fluctuation in the real pound-dollar exchange rate are explained to the tune of 19 to $60 \%$ for monetary shocks and 4 to $26 \%$ for fiscal and productivity shocks.

Chamie et al. (1994) have tried to compare the shocks affecting the US and European currency areas. Using industrial production, consumer prices and the monetary aggregates, they identified three shock types: supply shock, demand shock and monetary shock. Their results show that the real supply and demand shocks affecting US regions are, on the whole, more symmetric than those experienced by European countries. However, Kalemli-Ozcan et al. (2001) believe that increased risk-sharing should reduce GDP asymmetry in the Eurozone. On the same launch, Gonzalez-Rozada \& Fanelli (2004) state that the supply shocks in the MERCOSUR countries tend to be greater than in the American and European countries.

Using data from the United States over the period 1995-2000, Mountford \& Uhlig (2009) identify two fiscal policy shocks using a VAR model: a government revenue shock and a government expenditure shock. According to their findings, the best fiscal policy to stimulate the US economy in the short run appears to be deficit-financed tax cuts.

Using a GMM approach, Nzimande \& Ngalawa (2017) investigates the influence of trade integration, financial integration, fiscal policy convergence, monetary policy similarity and oil prices on the degree of business cycle synchronization in the Southern African Development Community (SADC) region. They conclude that fiscal policy convergence and monetary policy similarity have a positive impact on the degree of business cycle synchronization. However, financial flows lead to divergent business cycles.

Despite the magnitude of divergent shocks in the ECOWAS zone, Tapsoba (2009) believes that the asymmetry of shocks can be mitigated by increased regional trade. Tsangarides \& Qureshi (2008) have highlighted the degree of divergence between the economies of WAEMU and WAMZ member countries and within WAMZ itself. Within WAMZ, there is a significant lack of homogeneity, with Nigeria and Ghana appearing as independent singletons. 
Moreover, although panel VAR models have not been the subject of a large literature, interesting studies have been conducted in developed and developing economies. Using Panel VAR model, Grossmann et al. (2014) study the dynamics of global exchange rate volatility. A panel of 29 countries over the period 1986-2011 was used to conduct this study. Their results show that exchange rate volatility responds to shocks to real GDP, foreign exchange reserves, interest rates, and the equity index, and that aggregate and highfrequency volatility is higher for developing countries. Lof \& Malinen (2014) also opted for a VAR panel to analyze the influence of public debt on economic growth in 20 developed countries. They concluded that the impact of sovereign debt on economic growth is not significant, but the opposite; economic growth has a negative and significant impact on debt in these countries.

The findings of the study conducted by Mehrara \& Mohaghegh (2011) reject the classic thesis of long-term monetary neutrality in net oil-exporting developing countries. In addition, they show the lack of inflationary effect of oil shocks in these countries and their significant impacts on economic activity and money supply.

Finally, in the WAEMU region, Ramde (2015) used a VAR panel to study the link between institutions, investment and growth. According to Ramde, socio-political instability, corruption, and poor regulation of economic activity have a negative impact on investment and economic growth in the member countries of the Union.

\section{Preliminary Analysis of the Data}

The study is conducted on a panel of eleven ECOWAS countries (Benin, Burkina Faso, Ivory Coast, Gambia, Ghana, Mali, Niger, Nigeria, Senegal, Sierra Leone and Togo) and covers the period 1977 - 2019. Cape Verde, Guinea, Bissau Guinea, and Liberia were excluded from the sample due to missing and incomplete data for some variables. In 2020, these four countries accounted for only $2.71 \%$ of the Community's GDP. It includes for each country the logarithms of real GDP (lrgdp), the price index (lpi) measured by the GDP deflator, the real exchange rate between the US dollar and national currencies (lrer), the money supply (lms) and government expenditure (lgpe). Thus, the ECOWAS economy is described by the following vector of endogenous variables:

$$
y_{i t}=\left(\begin{array}{c}
l m s_{i t} \\
l r e r_{i t} \\
l p e_{i t} \\
l r g d p_{i t} \\
l p i_{i t}
\end{array}\right)
$$

These five macroeconomic variables (three real and two nominal variables) will be used to identify the macroeconomic shocks likely to weaken the future ECOWAS monetary zone.

The first variable on which we will rely is production, measured by real GDP. Indeed, it allows us to capture the impact of supply or demand shocks on production. Real GDP is in millions of US dollars. The second real variable on which we will rely is the bilateral real exchange rate between the US dollar and the national currency of each member country. It is measured by the ratio of price levels multiplied by the nominal exchange rate as follows. 


$$
r e r=\frac{P^{*}}{P} E
$$

where $r e r$, real exchange rate between the US dollar and the national currency; $E$ nominal exchange rate $\$ / X O F, \$ / G M D, \$ / G H S, \$ / S L L, \$ / N G N ; P^{*}$ the US price index and $P$ the national price index. The choice of the real exchange rate is justified by the fact that it is considered a transmission mechanism for monetary shocks and has an impact on macroeconomic variables, particularly on the price level and real GDP. Monetary policy shocks are modelled here by the change in the money supply. As for the price index, we used the GDP deflator, which measures inflation. Finally, the government expenditure variable was also chosen as the variable of interest to measure the impact of fiscal shocks.

The length of the sample and the frequency are imposed by the availability of data. These data come from the following databases: Center for Prospective Studies and International Information (CEPII), the World Development Indicators (WDI), International Financial Statistics (IFS) and the central banks and statistical agencies of the countries in the sample.

\subsection{Descriptive Statistics}

Table 1 presents the mean, median, maximum, standard deviation and number of observations of series and indicates a high dispersion around the mean for all variables.

Table 1: Panel Summary Statistics

\begin{tabular}{|l|c|c|c|c|c|}
\hline Variable & Obs & Mean & Std. Dev. & Min & Max \\
\hline Money supply & 473 & 25.52 & 3.29 & 12.63 & 31.18 \\
\hline Real exchange rate & 473 & 5.49 & 1.98 & -0.98 & 8.52 \\
\hline Public expenditure & 473 & 20.32 & 1.51 & 17.22 & 24.82 \\
\hline Real GDP & 473 & 8.87 & 1.42 & 6.10 & 12.88 \\
\hline Price index & 473 & 3.42 & 1.90 & -5.46 & 5.89 \\
\hline
\end{tabular}

Note: All variables are in logarithms

The average real exchange rate in logarithms is 5.49 with a range of -0.98 (Ghana in 1982 ) to 8.52 (Sierra Leone 1986). Indeed, for the same product, the price is higher in Sierra Leone than in the United States compared to other countries in the sub-region. As a

Figure 1: Average Real Exchange Rate by Country

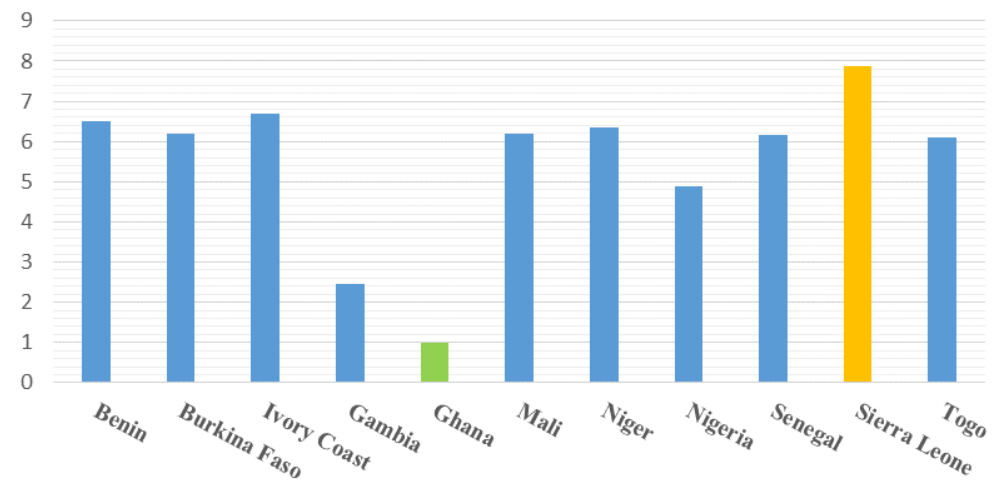

Source Authors' calculations 
result, Sierra Leone is the most undervalued currency relative to the dollar.

Figure 2: Average Public Expenditure by Country

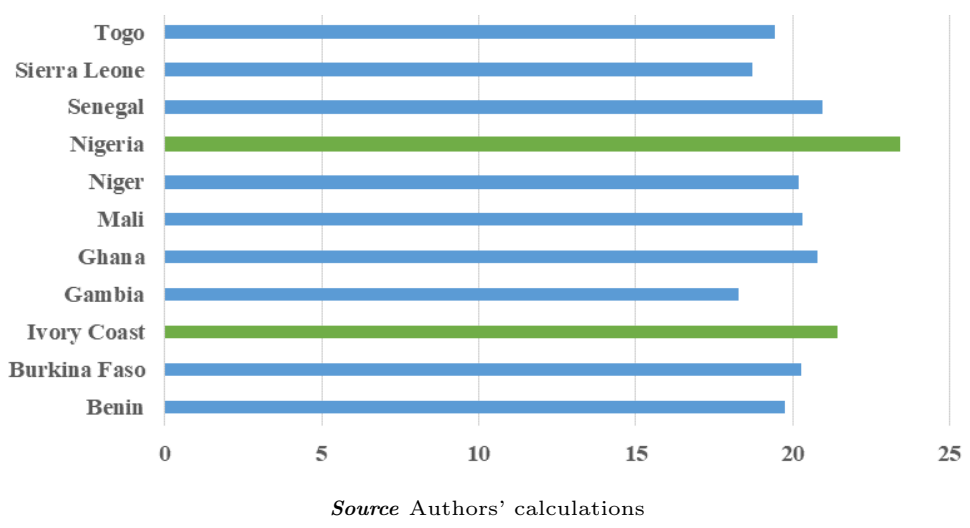

Consequently, prices are higher in Sierra Leone, with an average of 4.39 above the community average (4.11). It is followed by The Gambia and Togo with 4.34 and 4.33 respectively. In contrast, we have Ghana with an average of 3.55, Ivory Coast 3.78 and Nigeria 3.90.

As for the public expenditure variable, the average is equal to 20.32 with a range from 17.22 (Gambia in 1986) to 24.82 (Nigeria in 2019).

Finally, the Community average real GDP is 8.87 with a range from 6.10 (Gambia in 1977) to 12.88 (Nigeria in 2019). The GDPs of Nigeria, Ghana, Ivory Coast and Senegal represented about $88.94 \%$ of the Community's GDP in 2019.

Figure 3: Average Real GDP by Country

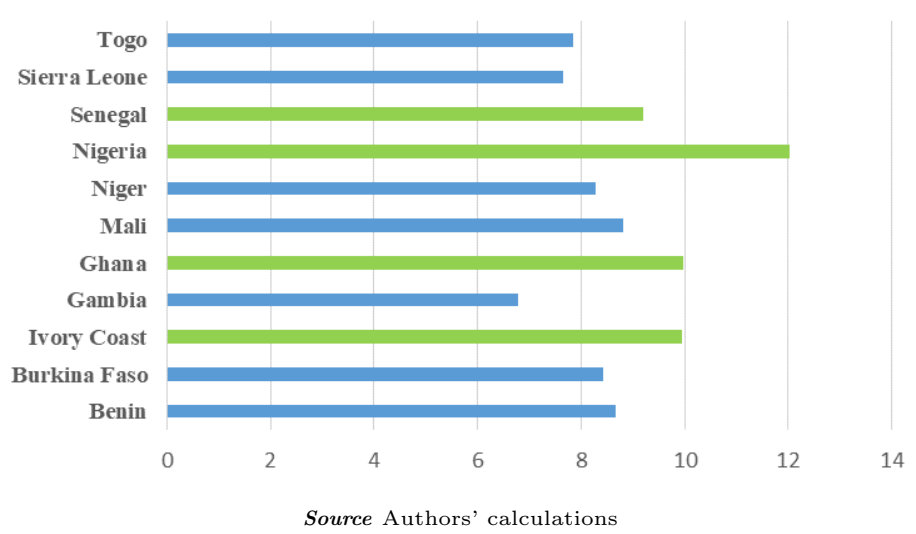

Examination of Figure 1 shows that for the same product, the price is higher in Sierra Leone than in the United States compared to other countries in the subregion. Therefore, Siearra Leone is the most undervalued currency against the dollar, trading at about $\$ 0.0004$ over the study period. The Ghanaian Cedi is the strongest currency against the dollar, followed by the Dalasi and the Naira. An increase in the price level in the member countries of the Union leads to a depreciation of the national currencies against the dollar. 
Analysis of the Figure 2 shows that the major economies of the Community have the highest public expenditure. Nigeria is in the first position, followed by Ivory Coast, Ghana and Senegal. Their averages are higher than the regional average. On the other side, we have the Gambia, Sierra Leone and Togo.

Figure 4: Average Price Index by Country

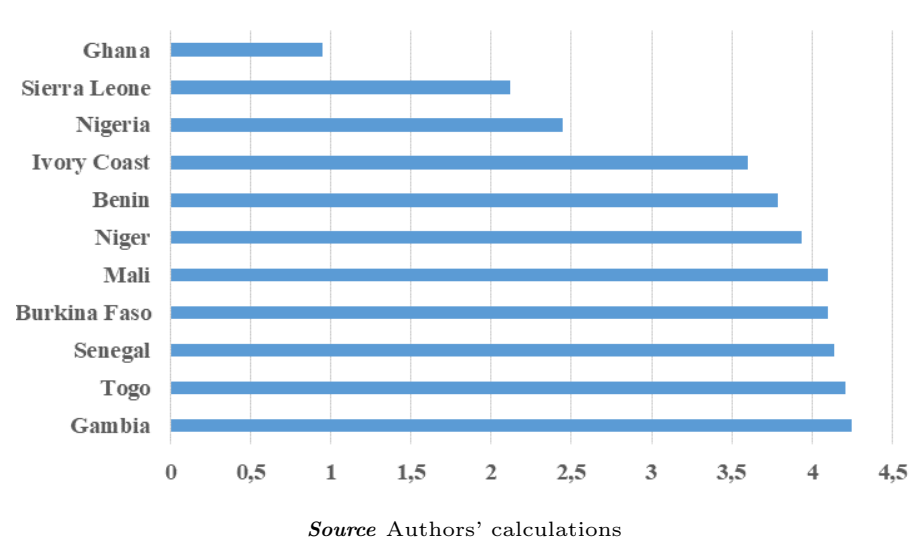

Analysis of Figure 3 shows a disparity in wealth creation in West Africa. Nigeria is well above the community average with 12.02 compared to 8.87. It is followed by Ghana 9.9842 , Ivory Coast 9.95 and Senegal 9.21. These four countries occupy in 2019 about $88.94 \%$ of wealth production in the area. On the other side, we have 6.78 for The Gambia and 7.65 million for Sierra Leone. It should be noted that about $66 \%$ of the total wealth of the subregion is produced by Nigeria.

Examination of Figure 4 shows, however, that with the exception of the Gambia, prices are lower in WAMZ countries than in WAEMU countries. Ghana, Sierra Leone and Nigeria have the lowest price indices in the Community over the study period.

\subsection{Cross-Sectional Dependence Test}

The Pesaran's test is used to test the cross-sectional dependence of each variable (Pesaran, 2007). The tests are based on the average of the pairwise correlation coefficients of the ordinary least squares residuals of each sample. The test statistic is as follows.

$$
C D=\sqrt{\frac{2 T}{N(N-1)}}\left(\sum_{i=1}^{N-1} \sum_{j=i+1}^{N} \hat{\rho}_{i j}\right)
$$

Under the null hypothesis, this statistic is asymptotically distributed according to a normal distribution. The hypotheses of the test are the following: $H_{0}$ : there is independence in cross-section ; $H_{1}$ : there is dependence in cross-section.

The test results reject the null hypothesis of cross-sectional independence at the $5 \%$ level for all variables, Table 2 . In other words, the variables are significantly dependent across cross-sections, there is a high degree of cross-sectional correlation, and a shock that occurs in one country will be transmitted to other countries. 
Table 2: Pesaran Cross-Sectional Dependence Test Results

\begin{tabular}{|l|c|c|c|c|}
\hline Variable & CD-test & P-Value & Corr & Abs (corr) \\
\hline Public expenditure & 39.43 & 0.000 & 0.820 & 0.820 \\
\hline Price index & 43.65 & 0.000 & 0.908 & 0.908 \\
\hline Money supply & 46.07 & 0.000 & 0.958 & 0.958 \\
\hline Real GDP & 44.81 & 0.000 & 0.932 & 0.932 \\
\hline Real exchange rate & 23.53 & 0.000 & 0.490 & 0.514 \\
\hline
\end{tabular}

\subsection{Pesaran Unit Root Test}

Stationarity plays an important role in the modelling of economic data. From a statistical point of view, a series is stationary if it has a constant mean, variance and covariance across observations. Unlike time series, the choice of the unit root test applied to panel data depends on the homogeneity or heterogeneity of the data.

First-generation stationarity tests assume inter-individual independence. The choice of the first-generation test depends on the homogeneity of the slope coefficients. If they are homogeneous, the tests developed by Levin \& Lin (1993); Levin et al. (2002) and Harris \& Tzavalis (1999) will be used. However, if they are heterogeneous, the tests developed by Im et al. (2003); Pesaran (2007) and Maddala \& Wu (1999) will be adopted.

As for the second generation unit root tests, they are based on the hypothesis of dependence between individuals. These tests were developed by Bai \& Ng (2004); Moon \& Perron (2004); Choi (2001) and Pesaran (2004, 2007).

Given the results of the cross-sectional dependence test, we will use Pesaran's secondgeneration stationary test. The author considers a one-factor model with heterogeneous loading factors for the residuals. It improves standard Dickey-Fuller or augmented DickeyFuller regressions with the cross-sectional average of lagged levels and first differences of individual series. This test is based on the assumption of no serial autocorrelation of errors. The null hypothesis of unit root is tested against the alternative hypothesis of stationary. The test statistic is as follows.

$$
C I P S(N, T)=\frac{\sum_{i=1}^{N} t_{i}(N, T)}{N}
$$

where $t_{i}(N, T)$ is the CADF for the $i^{t h}$ unit of the cross section given by the t-ratio of $\rho_{i}$ in the regression of the CADF.

Table 3: CADF Panel Unit Root Test Results

\begin{tabular}{|l|c|c|c|c|}
\hline & \multicolumn{2}{|c|}{ In level } & \multicolumn{2}{c|}{ First difference } \\
\hline Variable & Constant and trend & Constant & Constant and trend & Constant \\
\hline Public Expenditure & -2.82 & -2.64 & $-5.93^{* * *}$ & $-5.82^{* * *}$ \\
\hline Price index & -2.47 & -2.12 & $-5.54^{* * *}$ & $-5.43^{* * *}$ \\
\hline Money supply & -1.47 & -1.38 & $-5.56^{* * *}$ & $-5.31^{* * *}$ \\
\hline Real GDP & -2.69 & -1.46 & $-5.92^{* * *}$ & $-5.76^{* * *}$ \\
\hline Real exchange rate & $-3.00^{* * *}$ & $-2.71^{* * *}$ & $-5.47^{* * *}$ & $-5.47^{* * *}$ \\
\hline
\end{tabular}

The results of the unit root test presented in Table 3 show that, with the exception of the real exchange rate (stationary in level), all the other variables are stationary in first 
difference. Consequently, it is necessary to test the hypothesis of a long-run equilibrium relationship between the variables.

\subsection{Pedroni Cointegration Test}

Cointegration is used to detect a long-term equilibrium relationship between two or more non-stationary time series. It was introduced into econometric analysis by Granger \& Newbold (1974) and subsequently developed by several authors, including Engle, Granger and Johansen. The analysis of cointegration in panel data raises several problems. Indeed, one must take into account the notions of inter-individual and intra-individual cointegration, the question of homogeneity or heterogeneity of the cointegration relationship and the form of the specification of inter-individual dependencies.

Pedroni (1999) proposes a cointegration test that takes into account heterogeneity among individual panel members, including heterogeneity in long-run cointegrating vectors as well as heterogeneity in the dynamics associated with short-run deviations from these cointegrating vectors. We test the null hypothesis that for each variable of interest are not cointegrated against the alternative hypothesis of cointegration. Pedroni proposes seven tests, four of which are based on the Within-dimension and the other three on the Between-dimension.

Table 4: Pedroni Cointegration Test Results

\begin{tabular}{|c|c|c|c|c|}
\hline & \multicolumn{2}{|c|}{$H_{1}:$ Within-dimension } & \multicolumn{2}{|c|}{$\mathrm{H}_{2}$ : Between-dimension } \\
\hline \multicolumn{5}{|c|}{ Model with constant } \\
\hline & P-Value & P-val (Weighted) & & P-val \\
\hline Panel v-Statistic & 0.067 & 0.152 & - & \\
\hline Panel rho-Statistic & 0.127 & 0.329 & Group rho-Statistic & 0.755 \\
\hline Panel PP-Statistic & 0.000 & 0.021 & Group PP-Statistic & 0.026 \\
\hline Panel ADF-Statistic & 0.107 & 0.033 & Group ADF-Statistic & 0.019 \\
\hline \multicolumn{5}{|c|}{ Deterministic intercept and trend } \\
\hline & P-Value & P-val (Weighted) & & $\mathrm{P}$-val \\
\hline Panel v-Statistic & 0.298 & 0.636 & - & \\
\hline Panel rho-Statistic & 0.947 & 0.894 & Group rho-Statistic & 0.984 \\
\hline Panel PP-Statistic & 0.000 & 0.272 & Group PP-Statistic & 0.033 \\
\hline Panel ADF-Statistic & 0.647 & 0.291 & Group ADF-Statistic & 0.216 \\
\hline
\end{tabular}

Table 4 reports the results of the Pedroni tests. The null hypothesis of no cointegration is accepted for three panel statistics and one group for the model with constant. For the trend model, we cannot reject it for three panel statistics and two groups at the $5 \%$ level. For the estimation of the model, we will differentiate the endogenous variables to make them stationary.

\subsection{Dumitrescu and Hurlin Causality Test}

Causality studies the influence of one variable on another. A stationary series $y$ is said to cause another series $z$ when knowledge of the past of $y$ leads to a different prediction of $z$ than one based solely on the past of $z$. Granger (1969) laid the foundations of causality analysis in 1969. Afterwards, Dumitrescu \& Hurlin (2012) have adopted his model to analyze causality in panels.

The Dumitrescu and Hurlin test assumes that there may be a causality for some individuals but not necessarily for all. This test is based on three key assumptions: 1) Individual residuals are independent and normally distributed and have finite heterogeneous variances; 
2) Individual residuals are independently distributed across groups; 3) The variables and are covariance stationary. The Wald statistic associated with the null hypothesis is:

$$
W_{N, T}=\frac{1}{N} \sum_{i=1}^{N} W_{i, T}
$$

where $W_{i, T}$ denotes the individual Wald statistics for the $i^{t h}$ cross-sectional unit.

Table 5: Dumitrescu and Hurlin Causality Test Results

\begin{tabular}{|l|c|c|c|}
\hline Nul Hypothesis & W-stat & Zbar-Stat & P-Value \\
\hline lpe does not homogeneously cause lms & 2.13 & 0.02 & 0.99 \\
lms does not homogeneously cause lpe & 7.87 & 8.49 & 0.00 \\
\hline lrgdp does not homogeneously cause lms & 4.22 & 3.10 & 0.00 \\
lms does not homogeneously cause lrgdp & 6.46 & 6.41 & $1 . \mathrm{E}-10$ \\
\hline lrer does not homogeneously cause lms & 2.71 & 0.87 & 0.39 \\
lms does not homogeneously cause lrer & 3.48 & 2.02 & 0.04 \\
\hline lpi does not homogeneously cause lms & 2.63 & 0.76 & 0.45 \\
lms does not homogeneously cause lpi & 3.97 & 2.74 & 0.01 \\
\hline lrgdp does not homogeneously cause lpe & 7.14 & 7.42 & $1 . \mathrm{E}-13$ \\
lpe does not homogeneously cause lrgdp & 2.63 & 0.76 & 0.45 \\
\hline lrer does not homogeneously cause lpe & 2.85 & 1.09 & 0.28 \\
lpe does not homogeneously cause lrer & 2.59 & 0.69 & 0.49 \\
\hline lpi does not homogeneously cause lpe & 5.20 & 4.55 & $5 . \mathrm{E}-06$ \\
lpe does not homogeneously cause lpi & 3.58 & 2.16 & 0.03 \\
\hline lrer does not homogeneously cause lrgdp & 3.57 & 2.14 & 0.03 \\
lrgdp does not homogeneously cause lrer & 3.49 & 2.03 & 0.04 \\
\hline lpi does not homogeneously cause lrgdp & 4.59 & 3.66 & 0.00 \\
lrgdp does not homogeneously cause lpi & 2.95 & 1.23 & 0.22 \\
\hline lpi does not homogeneously cause lrer & 2.20 & 0.13 & 0.90 \\
lrer does not homogeneously cause lpi & 6.87 & 7.01 & $2 . \mathrm{E}-12$ \\
\hline
\end{tabular}

The test results presented in Table 5 show three bidirectional causal relationships from real GDP to the money supply, from the price index to government spending, and from the real exchange rate to real GDP. In addition, we found six unidirectional causal relationships, money supply $\rightarrow$ government spending, money supply $\rightarrow$ real exchange rate, money supply $\rightarrow$ price index, government spending $\rightarrow$ real GDP, price index $\rightarrow$ real GDP and exchange rate $\rightarrow$ price index. Therefore, the order of the variables in the VAR panel is: money supply $\rightarrow$ real exchange rate $\rightarrow$ government expenditure $\rightarrow$ price index $\rightarrow$ real GDP.

\section{Methodology}

\subsection{Panel VAR Specification}

Developed by Sims (1980), the VAR model allows economic fluctuations to be modelled using a small number of restrictions. Indeed, it describes the dynamic behavior of a vector of $\mathrm{K}$ variables that depend linearly on the past. Moreover, in VAR modeling, only the data decide the possible relationships between the variables. Even though, Collard \& Fève (2008) argue that DSGE (Dynamic Stochastic General Equilibrium) models should be preferred to VAR models, especially when it comes to identifying structural shocks and their effects on aggregate dynamics, VAR models have shown their performance in studying the dynamic relationships between variables and the propagation of shocks within an economic system. 
Moreover, the use of panel data is justified by the fact that they have several advantages. They allow for the capture of relevant relationships between variables over time; have the capacity to provide convergent estimators even when this information is missing; allow for the control of unobservable heterogeneity between individuals and the collinearity between explanatory variables is low. On the other hand, the ECOWAS countries do not have enough data over a long period of time to estimate the model for each country. Therefore, the use of panel data could significantly increase the efficiency and power of our estimates.

The panel VAR models (Holtz-Eakin et al., 1988) have an identical structure to that of the VARs, but a cross-sectional dimension is added to the representation. Let us consider the following p-order VAR panel composed only of endogenous variables:

$$
Y_{i t}=A_{1} Y_{i t-1}+A_{2} Y_{i t-2}+\ldots+A_{p-1} Y_{i t-p+1}+A_{p} Y_{i t-p}+\mu_{i}+\epsilon_{i t}
$$

where $i=1, \ldots, N$ and $t=1, \ldots, T$. This equation can be rewritten as:

$$
Y_{i t}=A_{i}(l) Y_{t-1}+\mu_{i}+\epsilon_{i t}
$$

where the vector of endogenous variables $Y_{i t}=\left(\Delta l m s_{i t}, \Delta l r e r_{i t}, \Delta l p e_{i t}, \Delta l r g d p_{i t}, \Delta l p i_{i t}\right)^{\prime}$ is a $5 \times 2$ matrix; $\mu_{i}$ is a $5 \times 1$ vector representing the country fixed effects; the $A_{i}(l)$ is the $5 \times 5$ matrix of coefficients and $\epsilon_{i t}=\left(\epsilon_{i t}^{l m s}, \epsilon_{i t}^{l r e r}, \epsilon_{i t}^{l p e}, \epsilon_{i t}^{l r g d p}, \epsilon_{i t}^{l p i}\right)^{\prime}$ is a $5 \times 1$ composite vector of macroeconomic innovations. We assume that the error term $\epsilon_{i t} \sim\left(0, \Sigma_{\epsilon}\right)$.

\subsection{Optimal Lag Length}

The choice of the number of lags in the VAR model is made by minimizing the information criteria. There are several methods (AIC, HQ, SC, FPE) that allow us not to arbitrarily fix the optimal number of lags. Andrews \& Lu (2001) proposed the MMSC (Model and Moment Selection Criteria) applicable to dynamic panel data models. The MMSC is based on Hansen (1982)'s J-statistic on overidentifying restrictions in order to select the optimal number of lags. The proposed criteria to select the pair of vectors $(p, q)$ that minimizes:

$$
M M S C_{n}(b, c)=J_{n}(b, c)-h(|c|-|b|)_{k_{n}}
$$

where $J_{n}(b, c)$ is the Hansen over-identification test statistic, b is the number of parameters, $\mathrm{c}$ is the number of moment conditions and $\mathrm{k}$ is the total number of observations. According to the results in Table 6, the first-order VAR model is the preferred.

Table 6: Optimal Lag Length

\begin{tabular}{|c|cccccc|}
\hline lag & CD & J & J-pvalue & MBIC & MAIC & MAIC \\
\hline 1 & 0.69 & 103.54 & 0.02 & -347.18 & -46.46 & -165.44 \\
2 & 0.76 & 70.31 & 0.03 & -230.13 & -29.69 & -109.02 \\
3 & 0.61 & 42.71 & 0.02 & -107.51 & -7.29 & -46.95 \\
\hline
\end{tabular}

\subsection{Stability Test}

The validation of a VAR requires that it is stable. A VAR is said to be stable when all its roots are inside the unit circle (Lütkepohl, 2005). Since all the roots of the VAR are inside the circle in Figure A.1, the VAR is stable, which implies stationarity. 


\section{Empirical Results}

\subsection{Impulse Response Functions}

Impulse analysis consists of determining the impact of a shock to one of the variables on the dynamics of the other variables. We showed in the previous Section A.1 that the Panel VAR is stable. This implies that the Panel VAR has a vector moving average (VMA) representation and that it is invertible. Therefore, the impulse response functions are obtained using the VMA representation of the VAR panel. The graphs of the impulse response functions show the effect of one standard deviation positive innovation of one of the variables on the other variables over a period of ten years. The first observation that is made here is that the curves oscillate towards zero, therefore, the VAR is stationary.

\subsubsection{Responses of the Community Economies to Macroeconomic Shocks}

Real GDP shock leads to a monetary contraction, disinflation and an appreciation of national currencies against the US dollar, Figure 5. The result is a drop in the cost of imported products, and consequently an increase in imports at the expense of exports. As a result, the Community's balance of trade has deteriorated which, in turn, has a negative impact on economic activity. However, it has a positive impact on public expenditure and

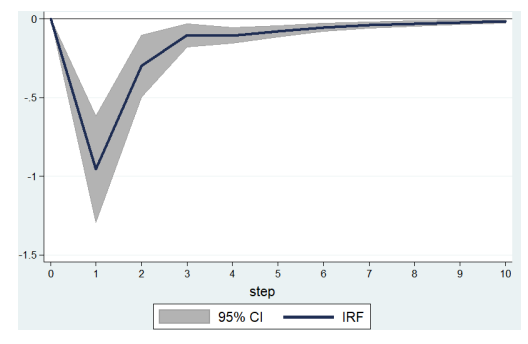

(a) Money Supply

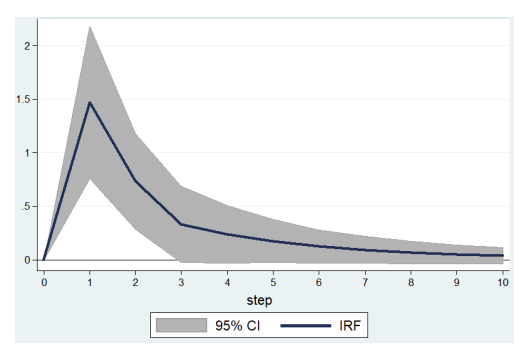

(c) Public Expenditure

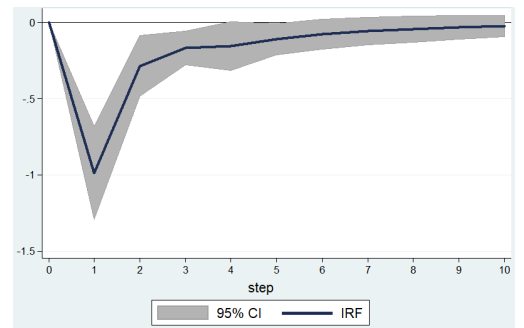

(b) Real Exchange Rate

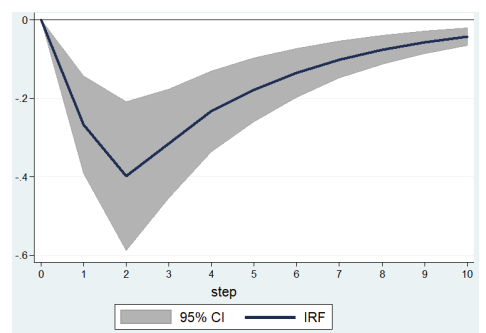

(d) Price Index

Figure 5: Impulse Responses to a Real GDP Shock

on the national currencies of ECOWAS member countries. The positive impact on public spending is explained by the well-known aggregate demand equation; $Y=C+I+G+X N$.

A fiscal shock creates a decrease in activity, an increase in the money supply, a depreciation of the real exchange rate and inflation, Figure 6. The increase in the money supply occurs at the time of the shock, and the effect becomes negative at two years before disappearing after seven years. The increase in the real exchange rate (national currency/US 


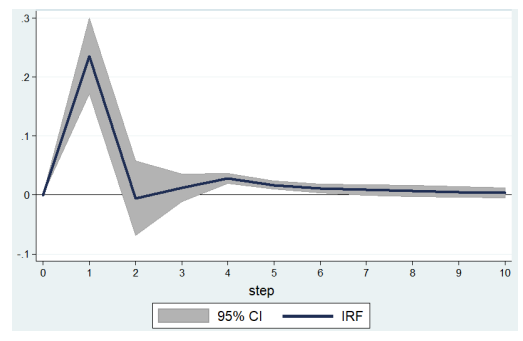

(a) Money Supply

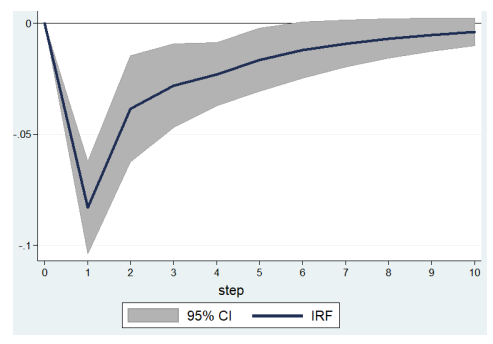

(c) Real GDP

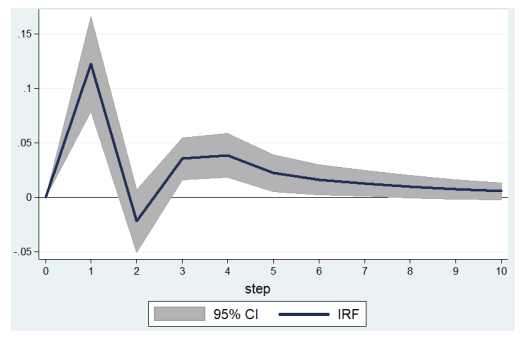

(b) Real Exchange Rate

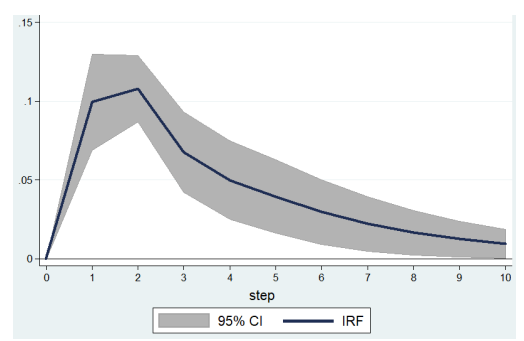

(d) Price Index

Figure 6: Impulse Responses to Government Spending Shock

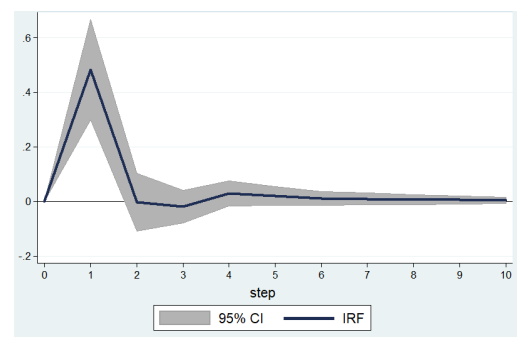

(a) Money Supply

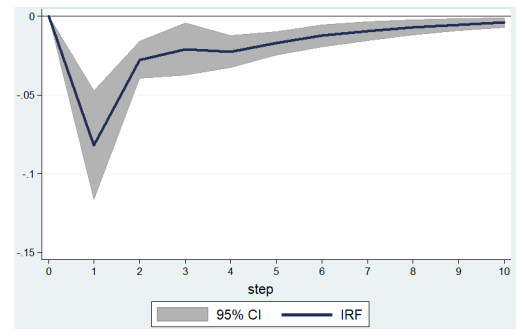

(c) Real GDP

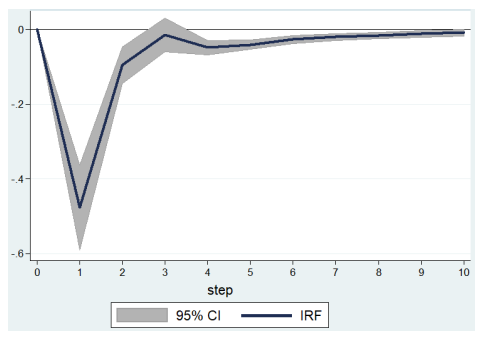

(b) Public Expenditure

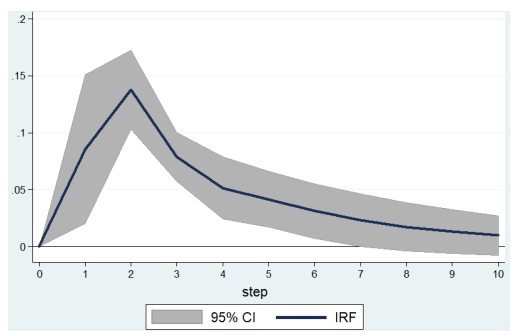

(d) Price Index

Figure 7: Impulse Responses to a Real Exchange Rate Shock

dollar) deteriorates the balance of trade and reduces demand for domestic goods. The negative impact on growth could be explained by the fact that, on the one hand, most of this expenditure is financed by borrowing. On the other hand, it is directed towards sectors that do not have a significant impact on growth. This result conforms with the findings of 
Olaoye et al. (2020). These authors found negative impacts of a positive public expenditure shock on real GDP in ECOWAS.

An exchange rate shock causes a decrease in government spending and output. However, it has a positive impact on the money supply and the price level (Figure 7).

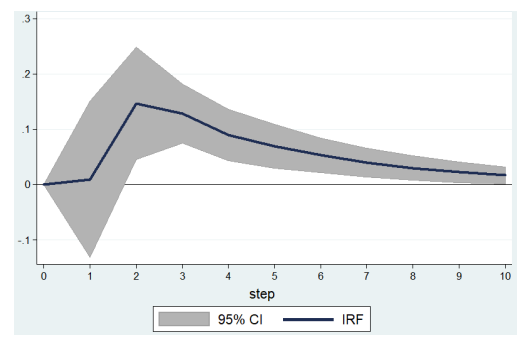

(a) Money Supply

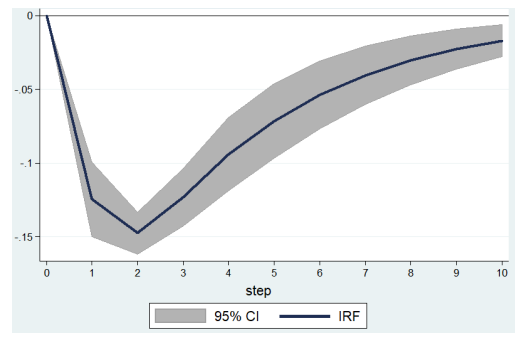

(c) Real GDP

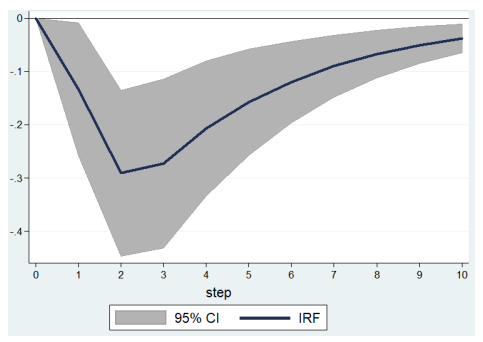

(b) Public Expenditure

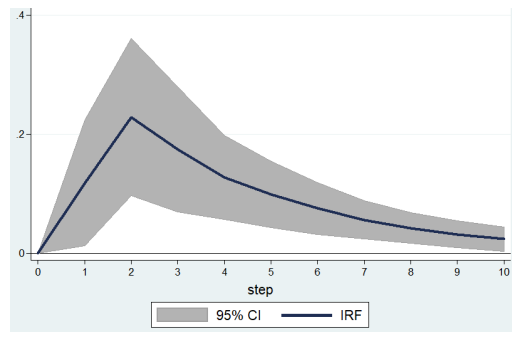

(d) Real Exchange Rate

Figure 8: Impulse Responses to a Price Shock

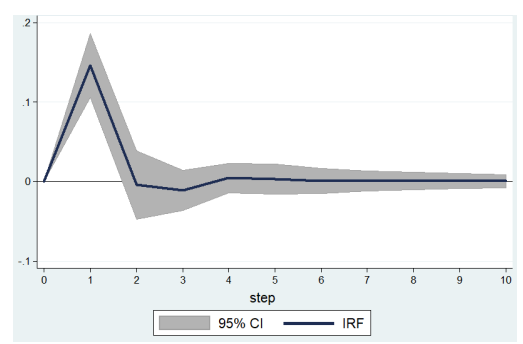

(a) Price Index

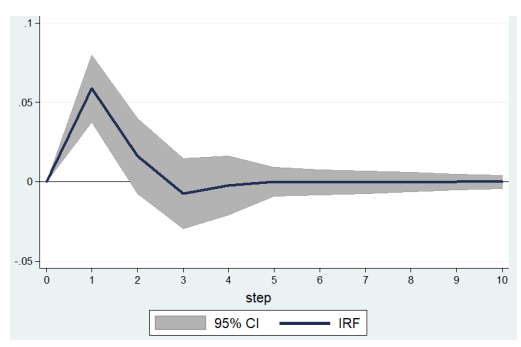

(c) Real GDP

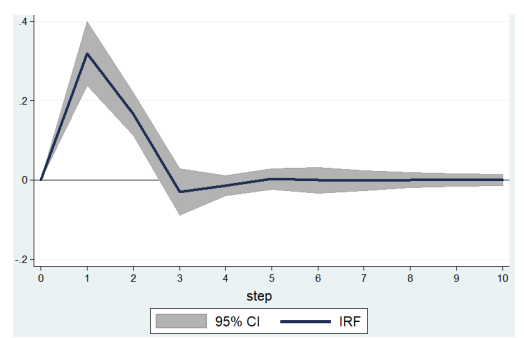

(b) Public Expenditure

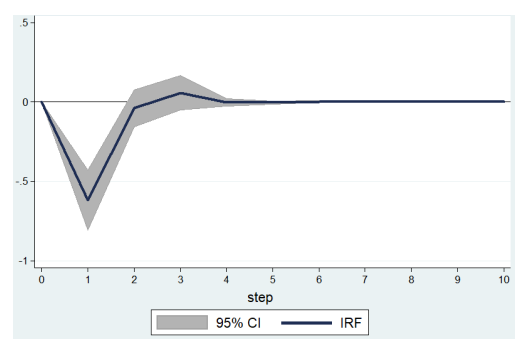

(d) Real Exchange Rate

Figure 9: Impulse Responses to a Monetary Policy Shock 
The impact of a price shock on the money supply is only significant after two years. Moreover, an increase in prices leads to a decrease in public spending, a decline in activity and an appreciation of the real dollar/national currency exchange rate of the Community countries (Figure 8). Consequently, an increase in exports from member countries and a decrease in imports as foreign goods become more expensive. The result is an improvement in the trade balance of ECOWAS economies.

Finally, a monetary policy shock causes inflation, increased government spending and higher economic growth. On the other hand, it causes national currencies to depreciate against the US dollar (Figure 9). The increase in the money supply increases the aggregate demand for goods by reducing the interest rate and stimulating investment. As a result, demand will exceed supply and, prices will rise to restore balance. Hence the positive impact on the price level. These results are not in contradiction with the results of Romer \& Romer (2004). According to the results of their study, a monetary policy shock has a positive and significant impact on real activity.

\subsubsection{Comparison of Impulse Response Functions in Currency Areas}

The main conclusion we make when comparing the impulse response functions (Figures A.2-A.6) of the two zones is that macroeconomic fluctuations in output, real dollar/national currency exchange rate, money supply, government spending and price indices have temporary effects on the WAEMU economies. On the other hand, there are long-term impacts on the WAMZ economies. For the WAEMU zone, shocks are amortized after six, seven years, whereas for the WAMZ, amortization is noted after ten years. The second finding is that the impact of shocks is more significant in the WAMZ than in WAMU. These results show that membership in a monetary union reduces the effect of economic shocks.

An analysis of the response of each of the variables to the innovations of the other variables shows the degree of asymmetry of the shocks between the two zones. With the exception of real exchange rate shocks, the two zones respond asymmetrically to innovations in the other variables. The real dollar/XOF exchange rate of the WAMU economies responds belatedly to a production shock, whereas for the WAMZ, the impact is immediate. The opposite is true for the response of the general price level. Disinflation occurs at the time of the shock in the WAMU economies before the price level increases after two years, whereas the response begins after one year for the WAMZ countries.

Similarly, asymmetric responses were noted for fiscal shocks. A negative effect on the money supply and an appreciation of national currencies were noted in WAMZ countries. On the other hand, they lead to a depreciation of the CFA against the dollar in WAEMU countries. A price shock has no significant impact on real GDP in the WAMU zone, whereas it is significant and negative at the time of impact and becomes positive after two years in the other zone. Monetary policy shocks have different impacts on the real exchange rate, government spending, real GDP and money supply variables in the two zones. They have a positive impact on public spending in WAMZ countries, whereas, for the WAEMU countries, the effect is negative at the time of the innovation and becomes positive after two years. The opposite effect is noted on the real GDP variable. A positive impact is noted for WAMU countries, and for WAMZ countries, the effect becomes negative after two years. Finally, a monetary shock causes disinflation in WAMU and inflation in the second zone. 


\subsection{Forecast Error Variance Decomposition (FEVD)}

Forecast error variance decomposition allows us to appreciate the impact of the variability of one variable on another. Tables 7 and 8 presents the forecast error variance decomposition of variables over a horizon of ten periods.

\subsubsection{Variance Decomposition of ECOWAS Economies}

Examination of Table 7 shows that $80 \%$ of future fluctuations in the money supply are due to its own shocks and $10 \%$ to real exchange rate shocks. As for the real exchange rate variable, about $73 \%$ of these future fluctuations are due to its own shocks and over $18 \%$ to monetary policy shocks. Less than $50 \%$ of future innovations in government spending are

Table 7: Forceast Error Variance Decomposition of ECOWAS economies

\begin{tabular}{|c|c|c|c|c|c|c|c|c|c|c|}
\hline Horizon & IMS & IRER & $\mathrm{IPE}$ & lRGDP & IPI & IMS & lRER & $\mathrm{lPE}$ & IRGDP & IPI \\
\hline & \multicolumn{5}{|c|}{ Money supply } & \multicolumn{5}{|c|}{ Real Exchange Rate } \\
\hline 1 & 1.000 & 0.000 & 0.000 & 0.000 & 0.000 & 0.072 & 0.928 & 0.000 & 0.000 & 0.000 \\
\hline 2 & 0.830 & 0.106 & 0.019 & 0.045 & 0.000 & 0.194 & 0.759 & 0.001 & 0.044 & 0.003 \\
\hline 3 & 0.819 & 0.105 & 0.020 & 0.051 & 0.005 & 0.190 & 0.745 & 0.003 & 0.051 & 0.012 \\
\hline 4 & 0.813 & 0.107 & 0.020 & 0.053 & 0.008 & 0.189 & 0.738 & 0.003 & 0.053 & 0.017 \\
\hline \multirow[t]{2}{*}{5} & 0.810 & 0.107 & 0.020 & 0.054 & 0.010 & 0.189 & 0.734 & 0.003 & 0.055 & 0.019 \\
\hline & \multicolumn{5}{|c|}{ Public Expenditure } & \multicolumn{5}{|c|}{ Real GDP } \\
\hline 1 & 0.022 & 0.288 & 0.689 & 0.000 & 0.000 & 0.010 & 0.003 & 0.062 & 0.926 & 0.000 \\
\hline 2 & 0.038 & 0.307 & 0.555 & 0.097 & 0.003 & 0.019 & 0.002 & 0.049 & 0.886 & 0.044 \\
\hline 3 & 0.047 & 0.289 & 0.522 & 0.125 & 0.018 & 0.017 & 0.012 & 0.042 & 0.837 & 0.092 \\
\hline 4 & 0.046 & 0.286 & 0.507 & 0.132 & 0.030 & 0.017 & 0.019 & 0.039 & 0.806 & 0.120 \\
\hline 5 & 0.046 & 0.283 & 0.500 & 0.135 & 0.037 & 0.016 & 0.020 & 0.038 & 0.791 & 0.135 \\
\hline \multicolumn{6}{|c|}{ Price Index } & & & & & \\
\hline 1 & 0.000 & 0.214 & 0.021 & 0.079 & 0.686 & & & & & \\
\hline 2 & 0.039 & 0.185 & 0.015 & 0.107 & 0.653 & & & & & \\
\hline 3 & 0.035 & 0.165 & 0.015 & 0.138 & 0.646 & & & & & \\
\hline 4 & 0.033 & 0.158 & 0.014 & 0.154 & 0.642 & & & & & \\
\hline 5 & 0.032 & 0.154 & 0.014 & 0.161 & 0.639 & & & & & \\
\hline
\end{tabular}

caused by its own shocks and more than $27 \%$ by real exchange rate shocks. Future changes in output are mainly due to output changes $(77 \%)$ and price shocks $(15 \%)$. Finally, price, real GDP, and fiscal shocks explain a significant part of the variance in the money supply, with $63 \%, 17 \%$, and $15 \%$, respectively.

\subsubsection{Variance Decomposition for WAEMU and WAMZ Economies}

The decomposition of the variance of the forecast error of the variables in the two zones presented in Table 8 shows that, in the WAEMU, $82 \%$ of the fluctuations in the money supply are due to its own shocks and $15 \%$ to government expenditure shocks. In the WAMZ, this percentage is $74 \%$ compared to $10 \%$ due to real exchange rate shocks. More than $67 \%$ of the variance in the real exchange rate is due to its own innovations in both zones, compared to $11 \%$ due to money supply shocks and $19 \%$ to fiscal shocks in WAEMU and more than $14 \%$ due to real GDP shocks in WAMZ.

As for fluctuations in public spending in the WAEMU, $67 \%$ is attributed to its own innovations, compared to $36 \%$ for the second monetary zone, and $20 \%$ compared to $35 \%$ are due to real exchange rate innovations. In the WAMZ, $18 \%$ of these variances are also due to real GDP shocks. 
Table 8: Forecast Error Variance Decomposition: WAEMU vs WAMZ

\begin{tabular}{|c|c|c|c|c|c|c|c|c|c|c|c|}
\hline & & \multicolumn{5}{|c|}{ WAEMU } & \multicolumn{5}{|c|}{ WAMZ } \\
\hline & Horizon & $\mathrm{lMS}$ & IRER & $\overline{\mathrm{lPE}}$ & lRGDP & IPI & lMS & IRER & $\mathrm{IPE}$ & IRGDP & IPI \\
\hline \multirow{5}{*}{$\begin{array}{l}\text { Money } \\
\text { Supply }\end{array}$} & 1 & 1.000 & 0.000 & 0.000 & 0.000 & 0.000 & 1.000 & 0.000 & 0.000 & 0.000 & 0.000 \\
\hline & 2 & 0.846 & 0.006 & 0.138 & 0.009 & 0.000 & 0.780 & 0.105 & 0.037 & 0.075 & 0.003 \\
\hline & 3 & 0.824 & 0.011 & 0.154 & 0.011 & 0.000 & 0.769 & 0.107 & 0.036 & 0.083 & 0.005 \\
\hline & 4 & 0.821 & 0.015 & 0.154 & 0.011 & 0.000 & 0.761 & 0.107 & 0.039 & 0.083 & 0.010 \\
\hline & 5 & 0.820 & 0.015 & 0.153 & 0.011 & 0.001 & 0.757 & 0.106 & 0.040 & 0.084 & 0.013 \\
\hline \multirow{5}{*}{$\begin{array}{l}\text { Real } \\
\text { Exchange } \\
\text { Rate }\end{array}$} & 1 & 0.079 & 0.921 & 0.000 & 0.000 & 0.000 & 0.030 & 0.970 & 0.000 & 0.000 & 0.000 \\
\hline & 2 & 063 & 0.716 & 0.203 & 0.004 & 0.015 & 0.037 & 0.880 & 0.027 & 0.055 & 0.001 \\
\hline & 3 & 099 & 0.682 & 0.200 & 0.004 & 0.015 & 0.039 & 0.822 & 0.053 & 0.083 & 0.003 \\
\hline & 4 & 0.111 & 0.674 & 0.195 & 0.004 & 0.016 & 0.036 & 0.783 & 0.069 & 0.102 & 0.010 \\
\hline & 5 & 0.112 & 0.672 & 0.195 & 0.004 & 0.016 & 0.035 & 0.754 & 0.076 & 0.116 & 0.020 \\
\hline \multirow{5}{*}{$\begin{array}{l}\text { Public } \\
\text { Expenditure }\end{array}$} & 1 & .070 & 0.218 & 0.712 & 0.000 & 0.000 & 0.001 & 0.357 & 0.643 & 0.000 & 0.000 \\
\hline & 2 & 0.100 & 0.203 & 0.682 & 0.010 & 0.006 & 0.003 & 0.429 & 0.507 & 0.061 & 0.000 \\
\hline & 3 & 0.101 & 0.201 & 0.681 & 0.011 & 0.006 & 0.005 & 0.439 & 0.438 & 0.114 & 0.003 \\
\hline & 4 & 0.106 & 0.202 & 0.675 & 0.011 & 0.006 & 0.006 & 0.423 & 0.415 & 0.141 & 0.015 \\
\hline & 5 & 0.107 & 0.202 & 0.673 & 0.011 & 0.006 & 0.006 & 0.405 & 0.403 & 0.157 & 0.030 \\
\hline \multirow{5}{*}{$\begin{array}{l}\text { Real } \\
\text { GDP }\end{array}$} & 1 & 0.021 & 0.013 & 0.052 & 0.914 & 0.000 & 0.004 & 0.000 & 0.150 & 0.846 & 0.000 \\
\hline & 2 & 0.217 & 0.073 & 0.156 & 0.543 & 0.010 & 0.009 & 0.003 & 0.116 & 0.798 & 0.073 \\
\hline & 3 & 0.315 & 0.109 & 0.130 & 0.430 & 0.015 & 0.008 & 0.017 & 0.106 & 0.727 & 0.142 \\
\hline & 4 & 0.338 & 0.116 & 0.123 & 0.405 & 0.018 & 0.012 & 0.022 & 0.102 & 0.685 & 0.180 \\
\hline & 5 & 0.340 & 0.116 & 0.124 & 0.402 & 0.019 & 0.013 & 0.022 & 0.100 & 0.665 & 0.201 \\
\hline \multirow{5}{*}{$\begin{array}{l}\text { Price } \\
\text { Index }\end{array}$} & 1 & 0.013 & 0.061 & 0.004 & 0.141 & 0.782 & 0.005 & 0.340 & 0.034 & 0.048 & 0.573 \\
\hline & 2 & 0.116 & 0.056 & 0.063 & 0.130 & 0.635 & 0.051 & 0.309 & 0.039 & 0.048 & 0.552 \\
\hline & 3 & 0.178 & 0.071 & 0.057 & 0.118 & 0.576 & 0.059 & 0.276 & 0.036 & 0.073 & 0.555 \\
\hline & 4 & 0.189 & 0.074 & 0.057 & 0.115 & 0.565 & 0.057 & 0.255 & 0.036 & 0.095 & 0.558 \\
\hline & 5 & 0.190 & 0.074 & 0.058 & 0.115 & 0.564 & 0.054 & 0.241 & 0.037 & 0.109 & 0.560 \\
\hline
\end{tabular}

In the WAMU, with the exception of prices, all the other variables explain future output fluctuations, with real GDP accounting for 40\%, money supply for 33\%, public spending for $12 \%$ and the real exchange rate for $11 \%$. However, in the other zone, they are attributable to variances in real GDP and the price index, with $63 \%$ and $23 \%$ respectively.

Finally, future price changes are due to its own innovations (50\%), real GDP shocks (11\%) and money supply shocks in the WAEMU zone, and to its own shocks (about 56\%), exchange rate innovations (21\%) and output shocks (13\%) in the WAMZ countries.

\section{Conclusions and Policy Implications}

The objective of this study was to examine the response of selected macroeconomic variables of ECOWAS economies to real and monetary shocks. A panel vector autoregression model was used to identify macroeconomic shocks of output, real exchange rate, price and economic policies (monetary and fiscal).

The results show that a monetary policy shock stimulates economic activity in ECOWAS economies while a fiscal shock dampens it. Similarly, fiscal policy shocks lead to a depreciation of national currencies against the dollar and monetary shocks to an appreciation of the latter. On the other hand, they both cause inflation. As for exchange rate and price shocks, they also have negative effects on output. Finally, these shocks have negative effects on public spending and positive effects on the Community's money supply.

The comparative analysis of the effects of innovations at the two currency areas (WAEMU and WAMZ) shows the degree of divergence of the economies that make up ECOWAS. Only 
the responses to real exchange rate shocks are symmetrical. Moreover, production shock leads to a depreciation of the CFA against the U.S. dollar and an appreciation of WAMZ currencies. The same is true of fiscal policy shock. However, it should be noted that price shocks do not affect the WAEMU money supply. This may be related to the price stability objective set by the Central Bank of West African States in terms of monetary policy. Finally, a fiscal policy shock leads to a decline in activity in both zones, whereas a monetary shock has the opposite effect, even if the positive impact on output in WAMZ countries is only short-term.

Furthermore, the decomposition of the variance of the forecast error shows that real exchange rate shocks contribute the most to future fluctuations in macroeconomic variables in ECOWAS economies. In WAEMU, government spending explains more than $15 \%$ of future fluctuations in the money supply, more than $19 \%$ of the variance in the real exchange rate and more than $12 \%$ of future variations in output. However, in the WAMZ, it is the real exchange rate that contributes the most to the future variations of the other variables, with $10 \%$ for the money supply, $35 \%$ for government spending and $21 \%$ for prices. Moreover, price fluctuations explain more than $23 \%$ of the variance in output in this zone.

Finally, the following economic policy implications will be drawn from this study:

- In order to achieve high growth, the countries of the Community will have to reduce or redirect their public spending. In addition, Community member countries must control their inflation rates.

- To meet the second-order convergence criterion on real exchange rates, ECOWAS countries should avoid the expansionary monetary policy. In addition, WAEMU countries should reduce their public spending and WAMZ countries should control their demands.

- In order to achieve the $5 \%$ inflation target, the countries of the Community must act on demand and the real exchange rate.

In this work, we have not isolated public consumption expenditure from investment expenditure. Several authors argue that the latter has a positive impact on economic growth. In our future studies, we will analyse the optimal exchange rate (fixed or flexible) to minimise the macroeconomic shocks that could weaken the future ECOWAS monetary zone.

\section{Acknowledgements}

This work was supported by the Research Laboratorie International Mixte Unit of Mathematical and Informatical Modelisation of the Complex Systems (UMMISCO/UCAD/IRD).

\section{References}

Andrews, D. W., \& Lu, B. (2001). Consistent model and moment selection procedures for GMM estimation with application to dynamic panel data models. Journal of Econometrics, 101(1), 123-164. doi:10.1016/S0304-4076(00)00077-4

Bai, J., \& Ng, S. (2004). A Panic attack on unit roots and cointegration. Econometrica, 72(4), 1127-1177. doi:10.1111/j.1468-0262.2004.00528.x 
Beetsma, R., Giuliodori, M., \& Klaassen, F. (2008). The effects of public spending shocks on trade balances and budget deficits in the European Union. Journal of the European Economic Association, 6(2-3), 414-423. doi:10.1162/JEEA.2008.6.2-3.414

Bernanke, B. S., \& Gertler, M. (1986). Agency costs, collateral, and business fluctuations. National Bureau of Economic Research. doi:10.3386/w2015

Blanchard, O., \& Perotti, R. (2002). An empirical characterization of the dynamic effects of changes in government spending and taxes on output. The Quarterly Journal of Economics, 117(4), 1329-1368. doi:10.1162/003355302320935043

Boiciuc, I. (2015). The effects of fiscal policy shocks in Romania. A SVAR Approach. Procedia Economics and Finance, 32, 1131-1139. doi:10.1016/S2212-5671(15)01578-6

Chamie, N., DeSerres, A., \& Lalonde, R. (1994). Optimum currency areas and shock asymmetry: a comparison of Europe and the United States (Bank of Canada Working Paper No. 94/1).

Choi, I. (2001). Unit root tests for panel data. Journal of International Money and Finance, 20(2), 249-272. doi:10.1016/S0261-5606(00)00048-6

Christiano, L. J., Eichenbaum, M., \& Evans, C. L. (1999). Chapter 2 Monetary policy shocks: What have we learned and to what end? In (Vol. 1, p. 65-148). Elsevier. doi:10.1016/S1574-0048(99)01005-8

Collard, F., \& Fève, P. (2008). Modèles VAR ou DSGE: que choisir? Economie prevision(2), 153-174. doi:10.3917/ecop.183.0153

Debortoli, D., \& Nunes, R. (2014). Monetary regime switches and central bank preferences. Journal of Money, Credit and Banking, 46(8), 1591-1626. doi:10.1111/jmcb.12160

Debrun, X., Masson, P., \& Pattillo, C. (2005). Monetary union in West Africa: who might gain, who might lose, and why? Canadian Journal of Economics/Revue canadienne d'économique, 38(2), 454-481. doi:10.1111/j.0008-4085.2005.00288.x

Dumitrescu, E.-I., \& Hurlin, C. (2012). Testing for Granger non-causality in heterogeneous panels. Economic Modelling, 29(4), 1450-1460. doi:10.1016/j.econmod.2012.02.014

Evans, C. L. (1992). Productivity shocks and real business cycles. Journal of Monetary Economics, 29(2), 191-208. doi:10.1016/0304-3932(92)90012-Q

Friedman, M., \& Schwartz, A. J. (1963). Front Matter. In A Monetary History of the United States, 1867-1960 (pp. i-vi). Princeton University Press. http://www. jstor.org/ stable/j.ctt7s1vp.1.

Gonzalez-Rozada, M., \& Fanelli, J. (2004). Business Cycles and Macroeconomic Policy Coordination in Mercosur (Econometric Society 2004 Latin American Meetings No. 328). Econometric Society. Retrieved from https://EconPapers.repec.org/RePEc: ecm:latm04:328 
Granger, C., \& Newbold, P. (1974). Spurious regressions in econometrics. Journal of Econometrics, 2(2), 111-120. doi:10.1016/0304-4076(74)90034-7

Granger, C. W. J. (1969). Investigating causal relations by econometric models and crossspectral methods. Econometrica, 424-438. doi:10.2307/1912791

Grossmann, A., Love, I., \& Orlov, A. G. (2014). The dynamics of exchange rate volatility: A panel VAR approach. Journal of International Financial Markets, Institutions and Money, 33, 1-27. doi:10.1016/j.intfin.2014.07.008

Hansen, L. P. (1982). Large sample properties of generalized method of moments estimators. Econometrica, 50(4), 1029-1054. doi:10.2307/1912775

Harris, R. D. F., \& Tzavalis, E. (1999). Inference for unit roots in dynamic panels where the time dimension is fixed. Journal of Econometrics, 91(2), 201-226. doi:10.1016/S03044076(98)00076-1

Holtz-Eakin, D., Newey, W., \& Rosen, H. S. (1988). Estimating vector autoregressions with panel data. Econometrica, 1371-1395. doi:10.2307/1913103

Houssa, R. (2008). Monetary union in West Africa and asymmetric shocks: A dynamic structural factor model approach. Journal of Development Economics, 85(1-2), 319-347. doi:10.1016/j.jdeveco.2006.05.003

Im, K. S., Pesaran, M. H., \& Shin, Y. (2003). Testing for unit roots in heterogeneous panels. Journal of Econometrics, 115(1), 53-74. doi:10.1016/S0304-4076(03)00092-7

Kalemli-Ozcan, S., Sorensen, B., \& Yosha, O. (2001). Regional integration, industrial specialization and the asymmetry of shocks across regions. Journal of International Economics, 55(1), 107-137. doi:10.1016/S0022-1996(01)00097-6

Kydland, F. E., \& Prescott, E. C. (1982). Time to build and aggregate fluctuations. Econometrica, 1345-1370. doi:10.2307/1913386

Levin, A., \& Lin, C.-F. (1993). Unit root tests in panel data: new results (University of California at San Diego, Economics Working Paper Series).

Levin, A., Lin, C.-F., \& Chu, C.-S. J. (2002). Unit root tests in panel data: asymptotic and finite-sample properties. Journal of Econometrics, 108(1), 1-24. doi:10.1016/S03044076(01)00098-7

Lof, M., \& Malinen, T. (2014). Does sovereign debt weaken economic growth? A panel VAR analysis. Economics Letters, 122(3), 403-407. doi:10.1016/j.econlet.2013.12.037

Lütkepohl, H. (2005). New introduction to multiple time series analysis. Springer Science \& Business Media. doi:10.1007/978-3-540-27752-1

Maddala, G. S., \& Wu, S. (1999). A comparative study of unit root tests with panel data and a new simple test. Oxford Bulletin of Economics and Statistics, 61(S1), 631-652. doi:10.1111/1468-0084.0610s1631 
Mati, S., Civcir, I., \& Ozdeser, H. (2019). ECOWAS common currency: how prepared are its members? Investigación económica, 78(308), 89-119. doi:10.2307/26632475

Mehrara, M., \& Mohaghegh, M. (2011). Macroeconomic dynamics in the oil exporting countries: a panel VAR study. International Journal of Business and Social Science, 2(21), 288-295.

Moon, H. R., \& Perron, B. (2004). Testing for a unit root in panels with dynamic factors. Journal of Econometrics, 122(1), 81-126. doi:10.1016/j.jeconom.2003.10.020

Mountford, A., \& Uhlig, H. (2009). What are the effects of fiscal policy shocks? Journal of Applied Econometrics, 24(6), 960-992. doi:10.1002/jae.1079

Nolan, C., Schaling, E., et al. (1996). Monetary policy uncertainty and central bank accountability. Bank of England London.

Nzimande, N. P., \& Ngalawa, H. (2017). The endogeneity of business cycle synchronisation in SADC: A GMM approach. Cogent Economics 83 Finance, 5(1), 1358914. doi:10.1080/23322039.2017.1358914

Olaoye, O. O., Eluwole, O. O., Ayesha, A., \& Afolabi, O. O. (2020). Government spending and economic growth in ECOWAS: An asymmetric analysis. The Journal of Economic Asymmetries, 22, e00180. doi:10.1016/j.jeca.2020.e00180

Pedroni, P. (1999). Critical values for cointegration tests in heterogeneous panels with multiple regressors. Oxford Bulletin of Economics and Statistics, 61(S1), 653-670. doi:10.1111/1468-0084.0610s1653

Pesaran, M. H. (2004). General diagnostic tests for cross-sectional dependence in panels. Empirical Economics, 1-38. doi:10.1007/s00181-020-01875-7

Pesaran, M. H. (2007). A simple panel unit root test in the presence of cross-section dependence. Journal of Applied Econometrics, 22(2), 265-312. doi:10.1002/jae.951

Ramde, F. (2015). Institution, investissements et croissance dans l'UEMOA: une approche panel VAR [Institution, investments and growth in WAEMU: a panel VAR approach] (MPRA Paper No. 82417). University Library of Munich, Germany. Retrieved from https://ideas.repec.org/p/pra/mprapa/82417.html

Robert Nobay, A., \& Peel, D. A. (2003). Optimal discretionary monetary policy in a model of asymmetric central bank preferences. The Economic Journal, 113(489), 657665. doi:10.1111/1468-0297.t01-1-00149

Rogers, J. H. (1999). Monetary shocks and real exchange rates. Journal of International Economics, 49(2), 269-288. doi:10.1016/S0022-1996(98)00057-9

Romer, C. D., \& Romer, D. H. (2004). A new measure of monetary shocks: Derivation and implications. American Economic Review, 94(4), 1055-1084. doi:10.1257/0002828042002651 
Sims, C. A. (1980). Macroeconomics and reality. Econometrica, 1-48. doi:10.2307/1912017

Tapsoba, S. (2009). Hétérogénéité des chocs et viabilité des unions monétaires en Afrique de l'Ouest. Revue economique et monetaire n-juin, 5, 38.

Tsangarides, C. G., \& Qureshi, M. S. (2008). Monetary union membership in West Africa: A cluster analysis. World Development, 36(7), 1261-1279. doi:doi.org/10.1016/j.worlddev.2007.06.019

\section{Appendices}

\section{Appendix A: Impulse Response Functions by Currency Areas}

Figure A.1: Stability Test Result

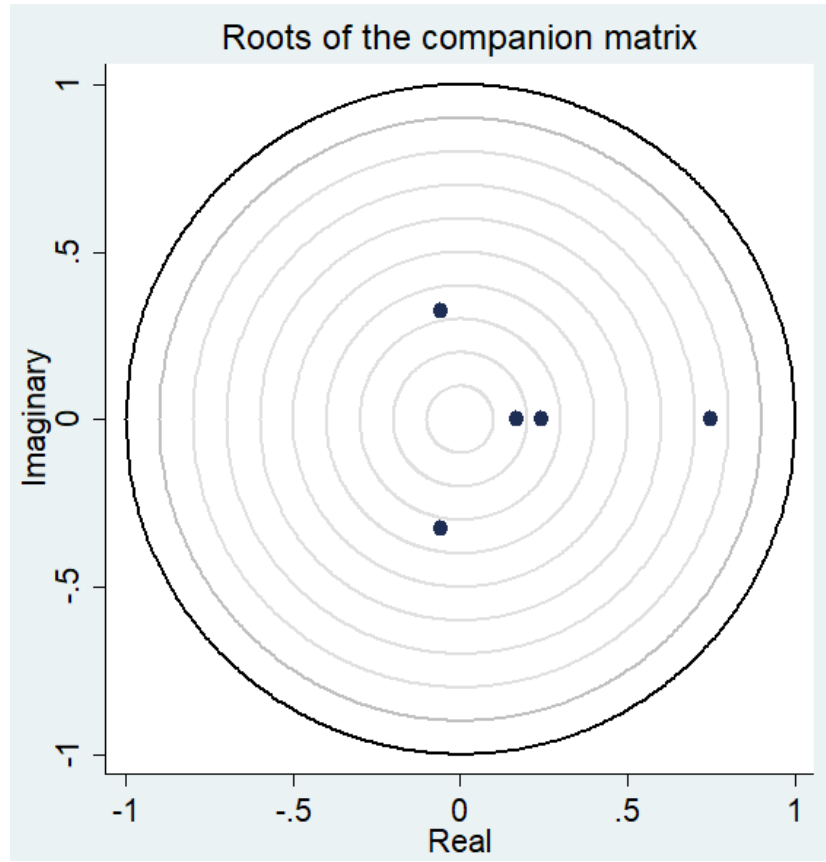




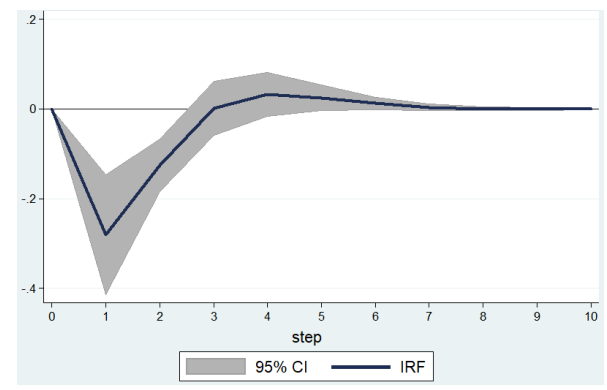

(a) Money Supply - WAEMU

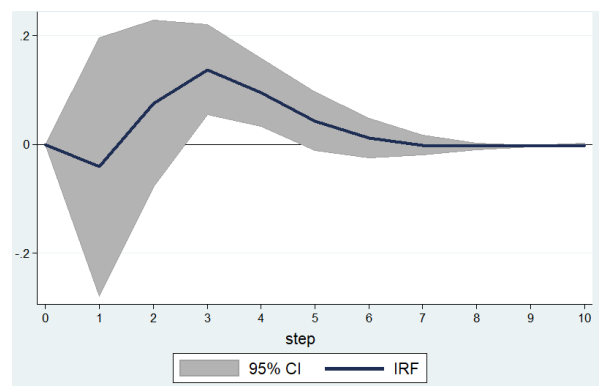

(c) Real Exchange Rate - WAEMU

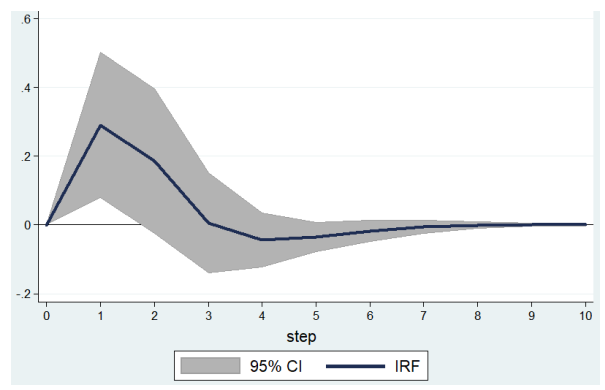

(e) Public Expenditure - WAEMU

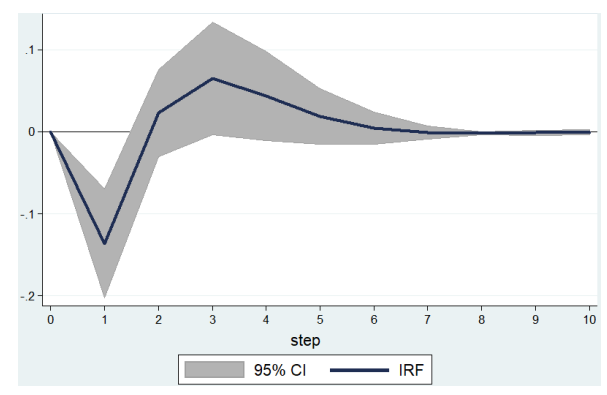

(g) Price Index - WAEMU

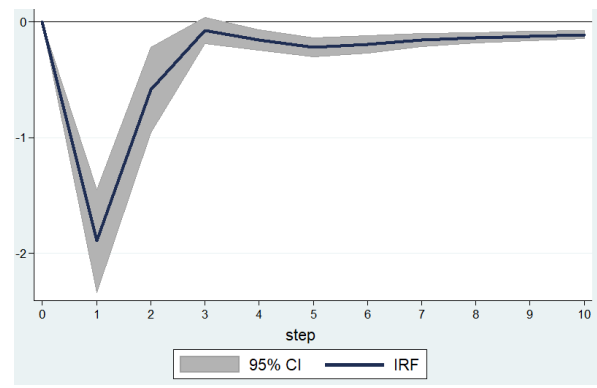

(b) Money Supply - WAMZ

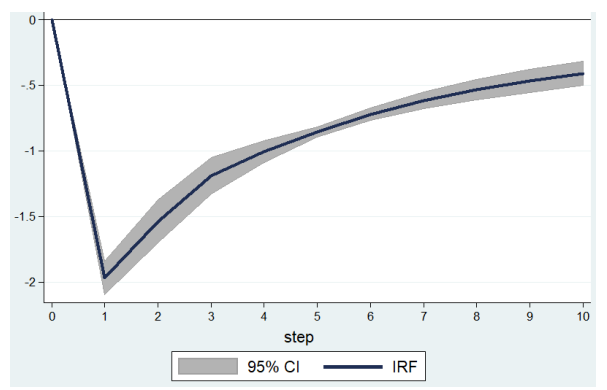

(d) Real Exchange Rate - WAMZ

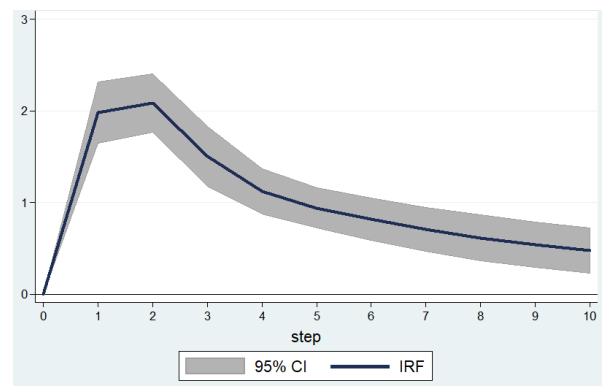

(f) Public Expenditure - WAMZ

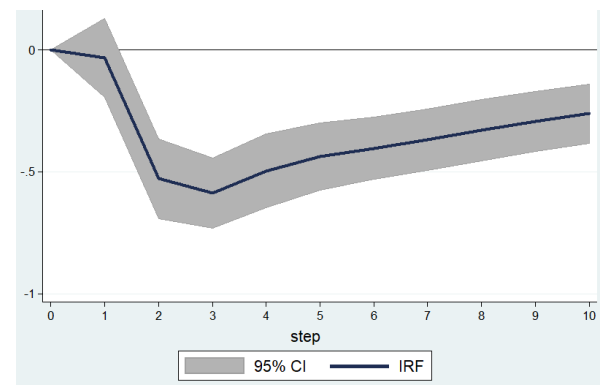

(h) Price Index - WAMZ

Figure A.2: Impulse Responses to a Real GDP Shock (WAEMU and WAMZ) 


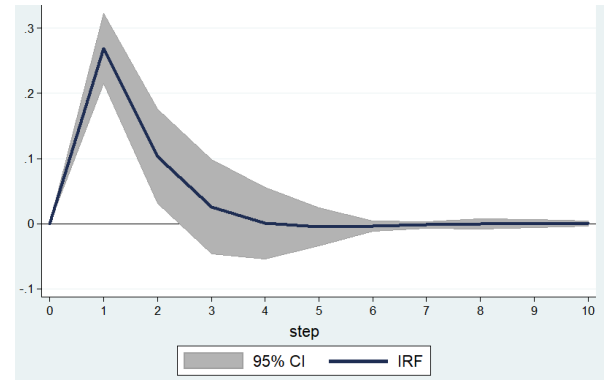

(a) Money Supply - WAEMU

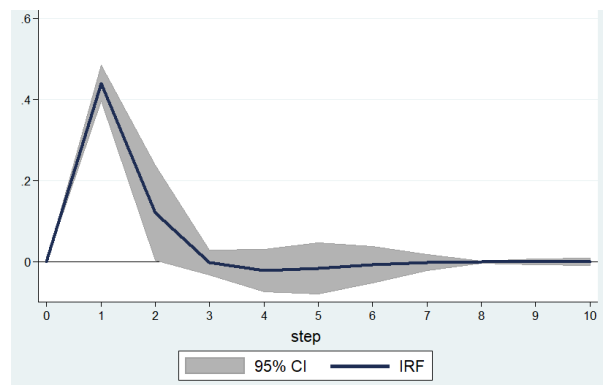

(c) Real Exchange Rate - WAEMU

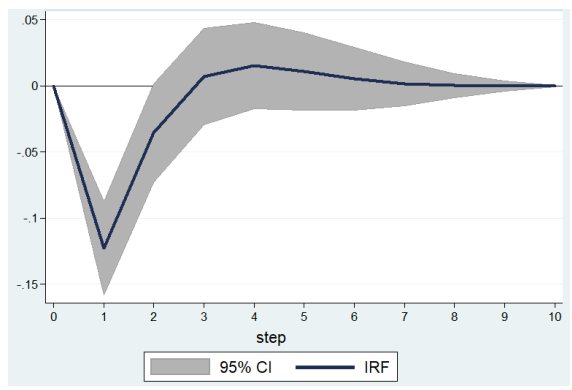

(e) Real GDP - WAEMU

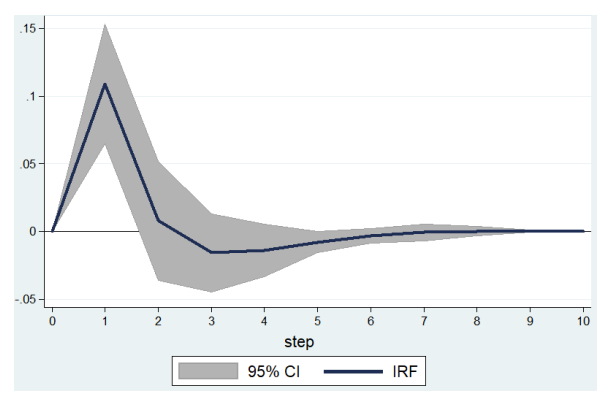

(g) Price Index - WAEMU

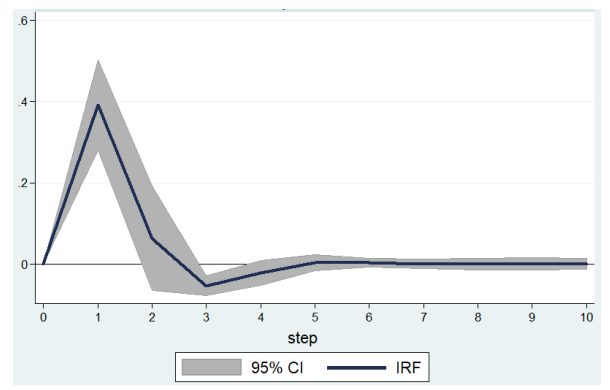

(b) Money Supply - WAMZ

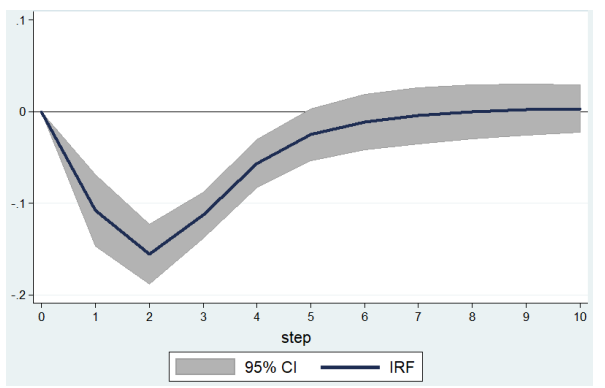

(d) Real Exchange Rate - WAMZ

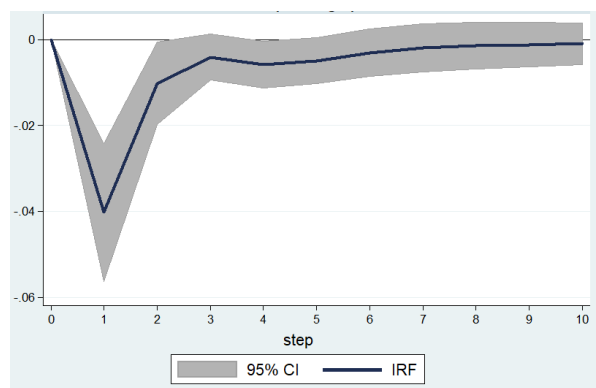

(f) Real GDP - WAMZ

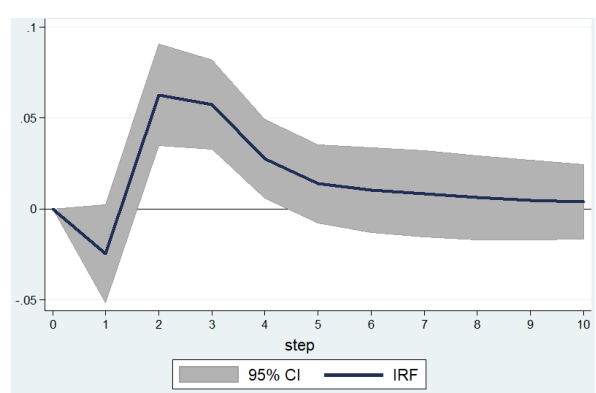

(h) Price Index - WAMZ

Figure A.3: Impulse Responses to a Public Spending Shock (WAEMU and WAMZ) 


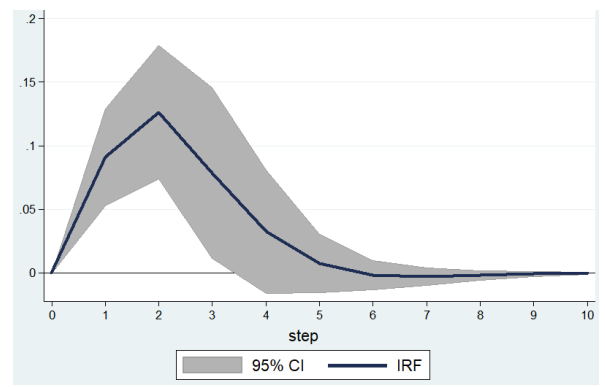

(a) Money Supply - WAEMU

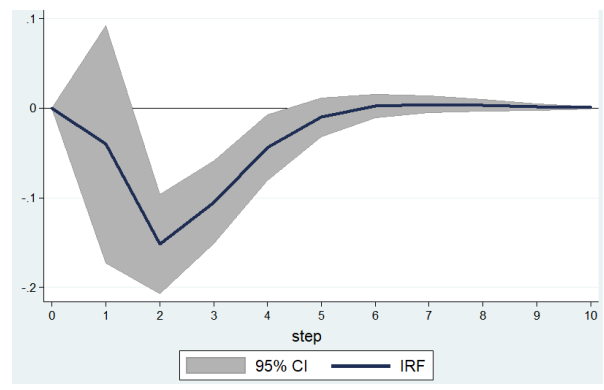

(c) Public Expenditure - WAEMU

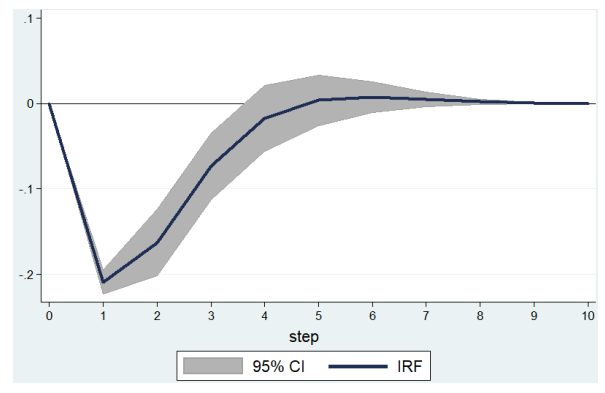

(e) Real GDP - WAEMU

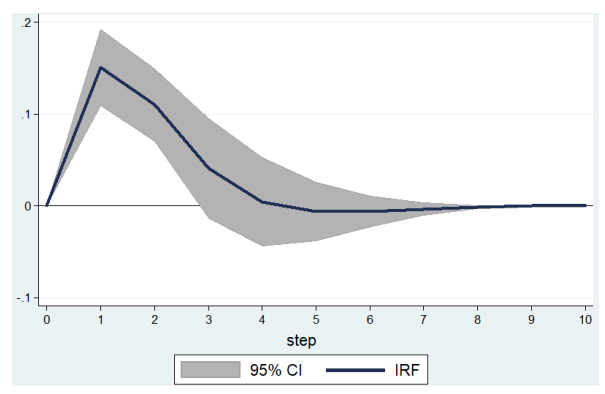

(g) Price Index - WAEMU

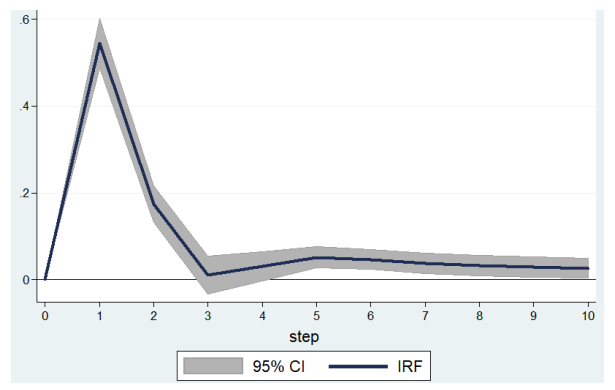

(b) Money Supply - WAMZ

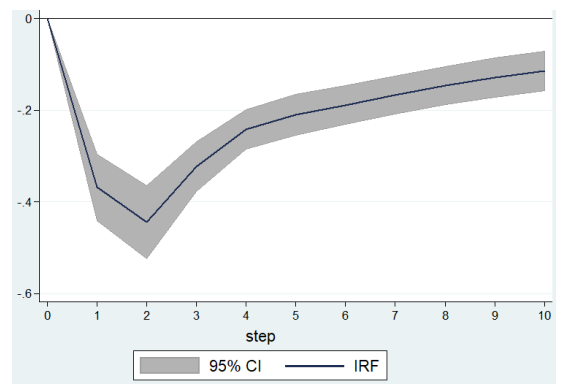

(d) Public Expenditure - WAMZ

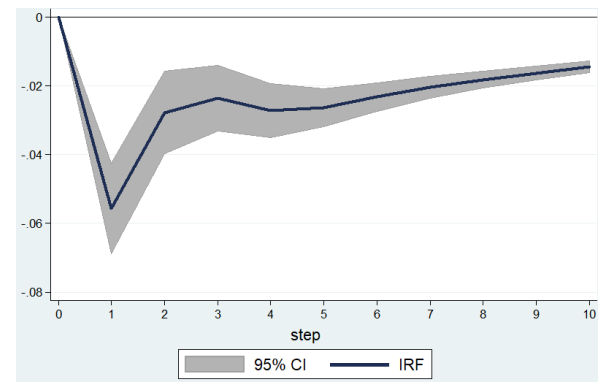

(f) Real GDP - WAMZ

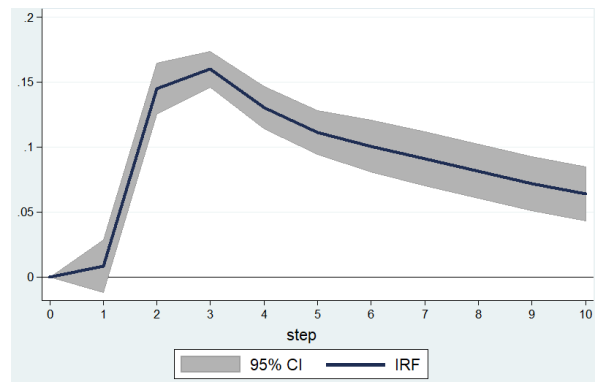

(h) Price Index - WAMZ

Figure A.4: Impulse Responses to a Real Exchange Rate Shock (WAEMU and WAMZ) 


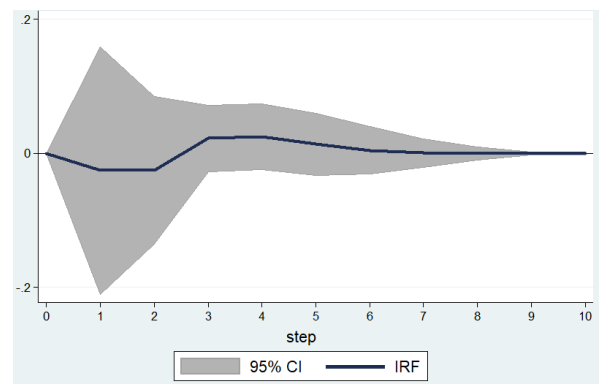

(a) Money Supply - WAEMU

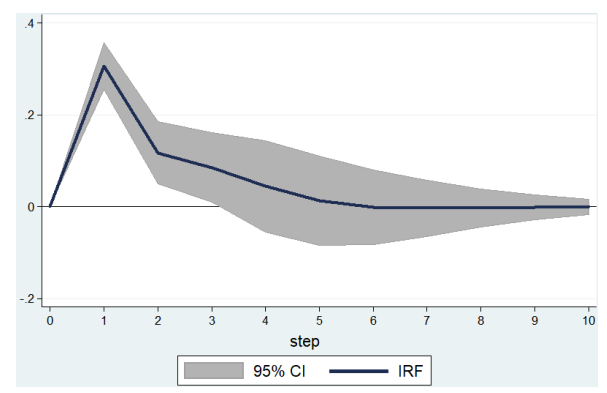

(c) Real Exchange Rate - WAEMU

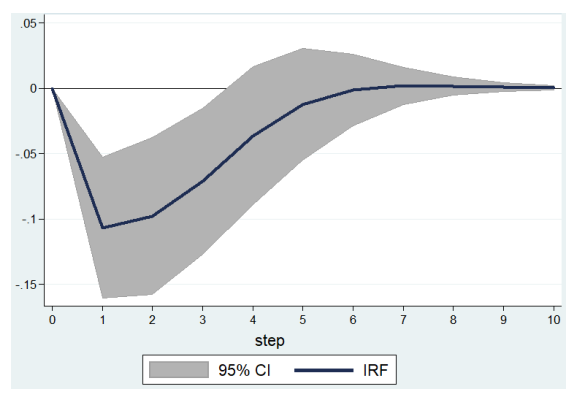

(e) Real GDP - WAEMU

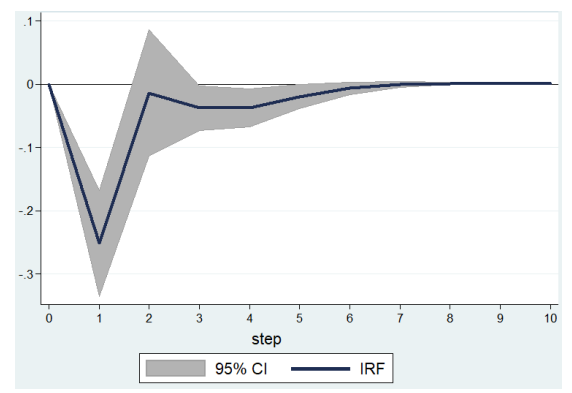

(g) Public Expenditure - WAEMU

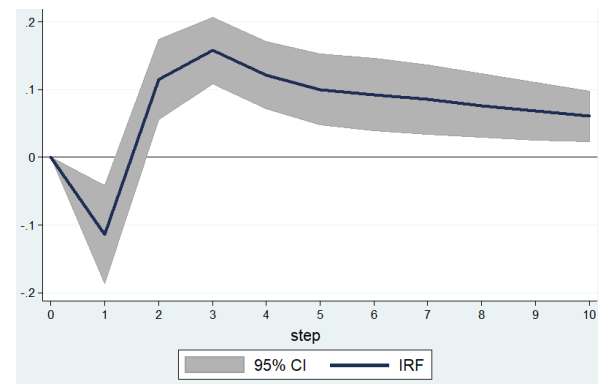

(b) Money Supply - WAMZ

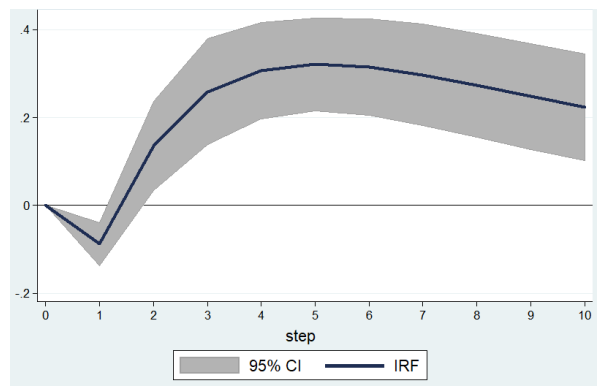

(d) Real Exchange Rate - WAMZ

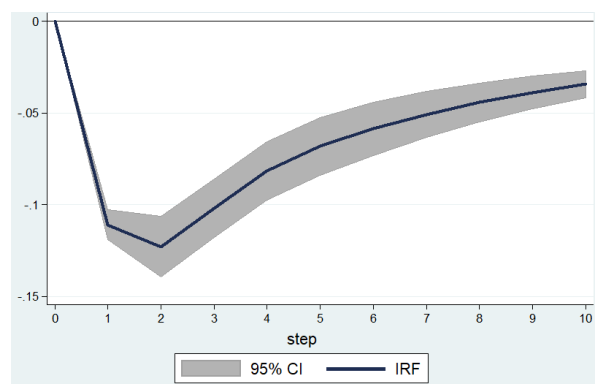

(f) Real GDP - WAMZ

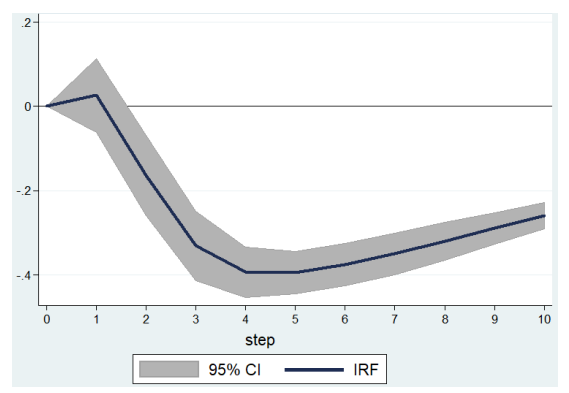

(h) Public Expenditure - WAMZ

Figure A.5: Impulse Responses to a Price Shock (WAEMU and WAMZ) 


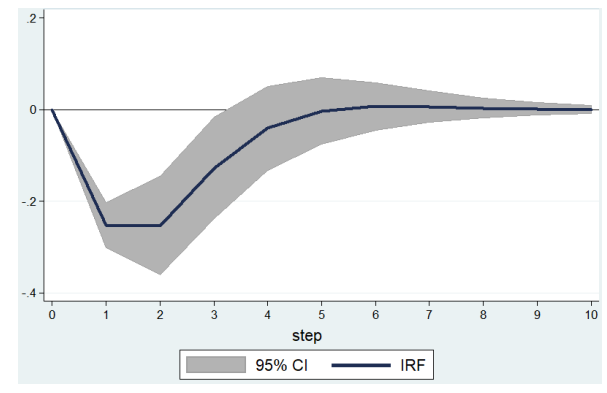

(a) Price Index - WAEMU

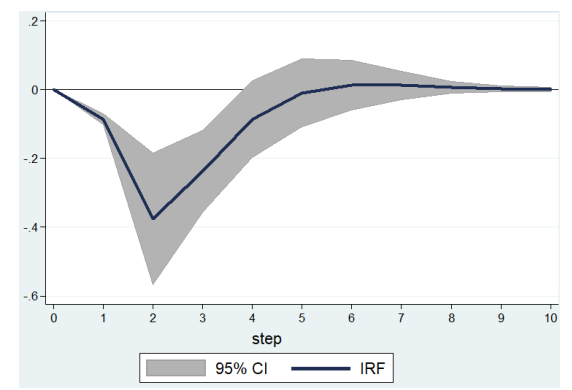

(c) Real Exchange Rate - WAEMU

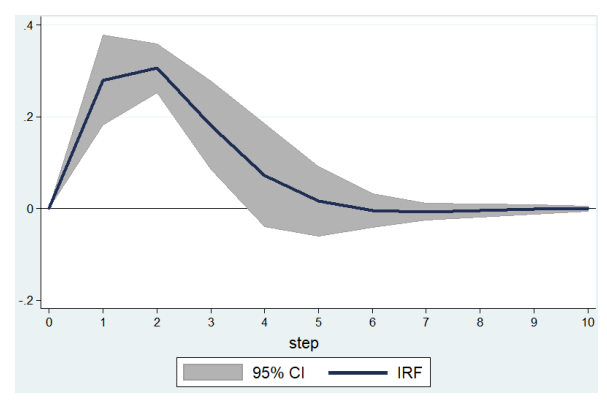

(e) Real GDP - WAEMU

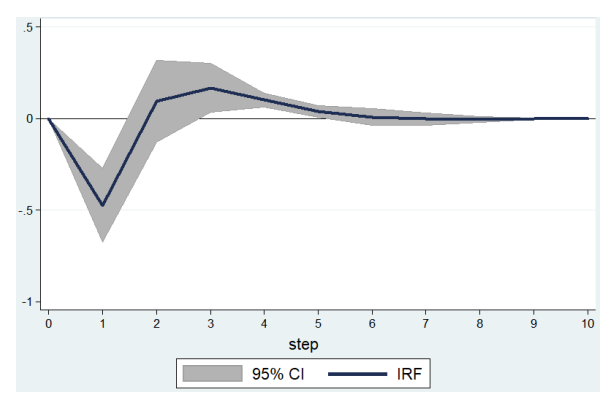

(g) Public Expenditure - WAEMU

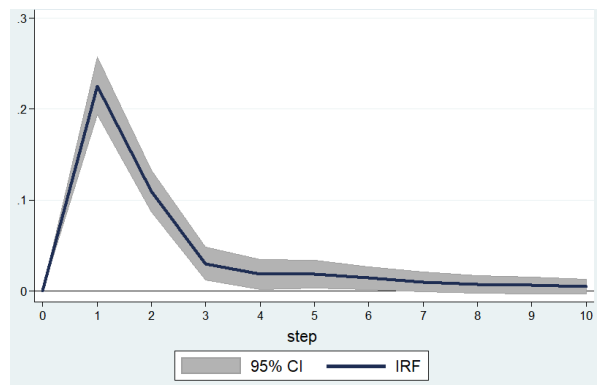

(b) Price Index - WAMZ

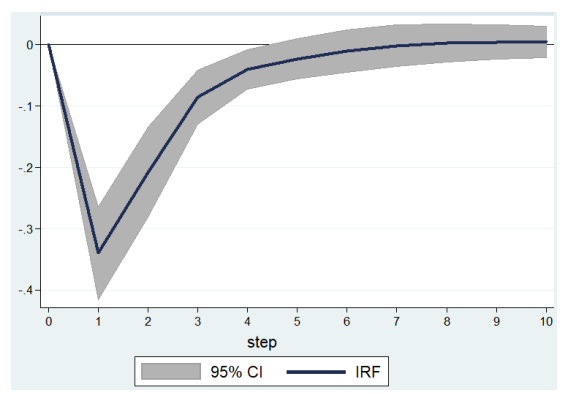

(d) Real Exchange Rate - WAMZ

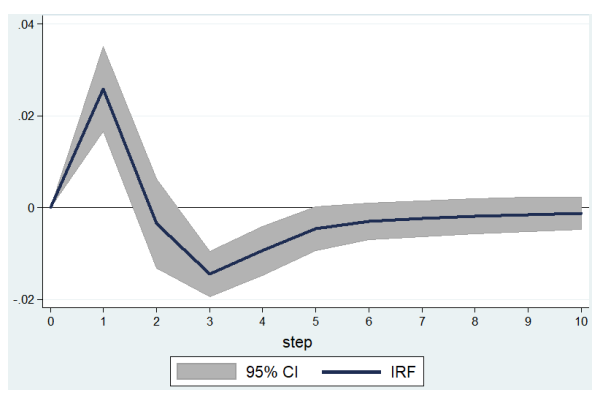

(f) Real GDP - WAMZ

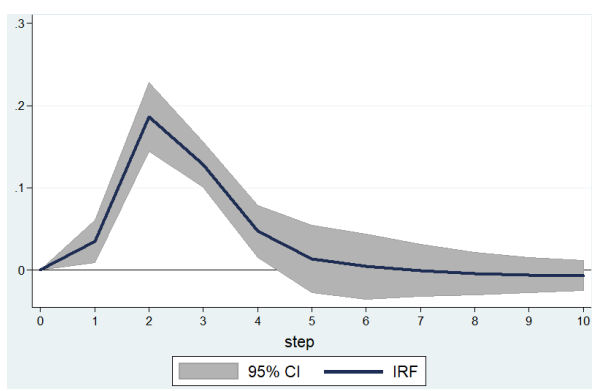

(h) Public Expenditure - WAMZ

Figure A.6: Impulse Responses to a Monetary Policy Shock (WAEMU and WAMZ) 